MONTANA DEPARTMENT OF CORRECTIONS Montana State Prison Execution Technical Manual

Effective Date: $01 / 16 / 2013$

Signed: 
TM 01/01.00 GENERAL PROVISIONS

TM 01/01.01 Purpose of Technical Manual

TM 01/01.01 Cross References

TM 01/01.03 Policy

TM 01/01.04 Definitions 
TM 01/01.00 GENERAL PROVISIONS

TM 01/01.01 Purpose of Technical Manual

A. The purpose of this technical manual is to provide the policies, procedures and post orders for carrying out the execution of a person sentenced to death.

B. This manual shall include policies and procedures related to:

1. planning and preparation;

2. execution of sentence;

3. post-execution requirements and process;

4. security and control;

5. witnesses and official visitors;

6. news media access and briefings;

7. delays, stays and commutations;

8. support services functions;

9. briefing and training; and

10. documentation, review and audit.

C. Post orders and checklists are included for staff and others involved in the execution planning, implementation, documentation and review.

TM 01/01.02 Cross Reference

A. Policies and Procedures

PD DI 501 Executions

PD 86-241 Security of Inmate Personal Property

B. Other Authority

MCA 46-19-103 Execution of death sentence

MCA 46-23-315 Authority of Governor to grant respite

TM 01/01.03 Policy 
It shall be the policy of Montana state Prison that:

A. the execution of persons sentenced to death under Montana law be carried out in the manner prescribed by law;

B. every effort is made in the planning and preparation of the execution event to ensure that the execution process:

1. adheres to the intent of the law as the prison understands it;

2. is handled in a manner which minimizes the negative impact on the safety, security and operational integrity of the prison;

3. accommodates the need for public access to information concerning the event;

4. reasonably addresses the privacy interests of those persons for whom the law, prison policy or commonly held principles of decency require such privacy;

5. provides sufficient backup to ensure that unplanned problems can be accommodated and overcome;

6. prepares for stays of execution, commutations and other delays in the execution countdown;

7. provides an opportunity for persons who wish to exercise their First Amendment right to demonstrate for or against capital punishment in a lawful manner;

8. ensures a firm and adequate response to unlawful civil disobedience, trespass, or other violations of the law by persons attempting to disrupt, prevent or otherwise frustrate the lawful process associated with the execution; and

9. anticipates and provides for sufficient support services, as needed, for the execution and the prison as a whole;

C. the prison shall facilitate the arrest and encourage the prosecution of persons including, but not limited to, those who:

1. trespass or otherwise enter prison property without proper permission and clearance;

2. participate in illegal demonstrations; 
3. illegally attempt or succeed in efforts to disrupt, prevent or otherwise interfere with the execution;

4. being inmates, are involved in disruptive, assaultive or other illegal behavior; or

5. illegally threaten, intimidate or otherwise terrorize persons involved in the execution process;

D. staff involved in the execution make every effort within the requirements and limits of these policies and procedures and the laws of the state of Montana to:

1. minimize the anxiety and negative impacts of the execution on the family and friends who are either visiting the condemned or witnessing the execution at the invitation of the condemned;

2. display appropriate levels of professionalism, restraint, and courtesy in interaction with witnesses, demonstrators, news media, and other non-staff persons during the execution process; and

3. not permit interactions, emotion or intimidation to prevent their proper handling of missions and duties;

E. staff is adequately prepared and de-briefed to minimize any anxiety and/or negative impacts on those affected by the execution process.

F. the prison review and audit the adequacy and/or the performance of :

1. the policies and procedures employed;

2. the prison staff members involved in the execution;

3. members of allied agencies assisting with the execution; and

4. statutes and other authority impacting the execution; and that

G. the evaluation of each execution be used to improve operational procedures for the future.

TM 01/01.04 Definitions

allied agency Refers to another criminal justice agency. 


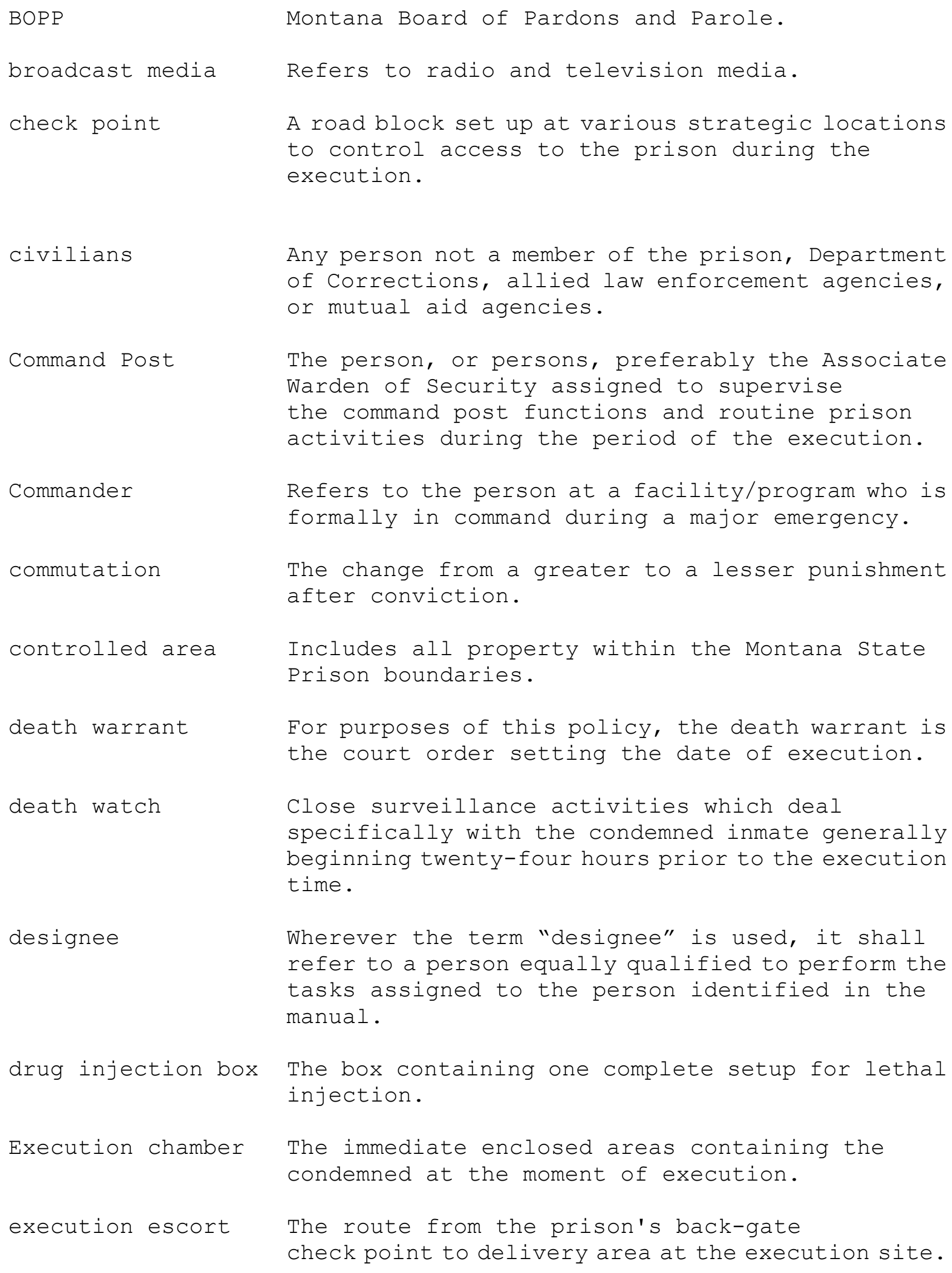
Execution chamber The immediate enclosed areas containing the check point to delivery area at the execution site.

Any person not a member of the prison, Department of Corrections, allied law enforcement agencies, or mutual aid agencies.

The person, or persons, preferably the Associate Warden of Security assigned to supervise the command post functions and routine prison activities during the period of the execution.

Refers to the person at a facility/program who is formally in command during a major emergency.

The change from a greater to a lesser punishment after conviction.

Includes all property within the Montana state Prison boundaries.

For purposes of this policy, the death warrant is the court order setting the date of execution.

Close surveillance activities which deal specifically with the condemned inmate generally beginning twenty-four hours prior to the execution time.

Wherever the term "designee" is used, it shall refer to a person equally qualified to perform the tasks assigned to the person identified in the manual.

The box containing one complete setup for lethal The route from the prison's back-gate 
execution site

holding cell

ISDP

media staging

mutual aid

news magazines

news media

news media

members

newspaper

Operations

Security Chief
The area, including the execution chamber, and adjacent outside areas used during the execution.

The final holding area where the condemned inmate is housed prior to the execution being carried out.

Inmate sentenced to the death penalty.

The area in the DoC Training Center (old National Guard Armory Building) where the alternate members of the news media (those who are not witnessing the execution) will be housed during the execution period.

Agencies or personnel that provide medical, fire suppression, law enforcement and other support services to the prison.

Magazines having a national circulation that are sold by newsstands to the general public and by mail circulation.

Collectively refers to those involved with news gathering for newspapers, news magazines, radio, television or news services.

Persons over the age of 18 who are primarily employed in the business of gathering or reporting news for newspapers, news magazines, national or international news services or radio or television stations licensed by the Federal Communications Commission.

For purposes of this manual, the publication:

1. circulates among the general public;

2. publishes legal notices in the community in which it is located or the area to which it distributes; and

3. contains items of general interest to public such as political, commercial, religious or social affairs.

Person who oversees the security measures associated with the execution process, appointed by the Warden or designee. 
pardon

Pre-execution cell One of two isolation cells in Locked Housing Unit-

I.

press

public assembly

against

reprieve

respite

security pass

Setup Officer

Qualified Person

An act of grace by the Governor exempting a person from punishment for a crime.

Refers to the print media. Also see "news media" generally.

The area at Check Point 1 , at the bottom of Golf Course Hill, where members of the public wishing to demonstrate either for or capital punishment may congregate.

The temporary suspension of the execution. See "reprieve".

A color-coded identification badge issued to witnesses, members of allied agencies, and the news media approved for admittance to prison property during the execution.

The person assigned to assist in preparing the condemned for execution and to carry out the duties in TM 01/PO5. At minimum, the Setup Officer shall have an EMT-Basic certification with IV/IO Initiation endorsement and at least one (1) year of experience in the routine insertion of intravenous catheters as a part of his or her regular job.

The person assigned to perform the consciousness check procedures of TM 01/05.12 G. 2.f. and g. At minimum, the Qualified Person shall be a medically trained individual whose training and experience include the ability to physically confirm a person's unconsciousness. As used in this definition only, a medically trained individual shall include any one of the following:

Emergency Medical Technician (EMT);

Licensed Practical Nurse (LPN);

Military Corpsman;

Paramedic;

Physician Assistant;

Physician;

Registered Nurse (RN) or, 
Other medically trained personnel including those trained in the United state military.

witness viewing The area from which the execution is viewed by the witnesses. 


$\begin{array}{ll}\text { TM 01/02.00 } & \text { PRE-EXECUTION CHECKLIST } \\ \text { TM 01/02.01 } & \begin{array}{l}\text { General Provisions } \\ \text { Re 01/02.02 }\end{array} \\ \begin{array}{ll}\text { Execution } \\ \text { Twenty-Nine to Fourteen Days Prior to the Execution }\end{array} \\ \text { TM 01/02.03 } & \text { Thirteen to Seven days Prior to the Execution } \\ \text { TM 01/02.05 } & \text { Six to Three Days Prior to the Execution } \\ \text { TM 01/02.06 } & \text { Forty-Eight to Twenty-Four Hours Prior to the Execution }\end{array}$


TM 01/02.00 PRE-EXECUTION CHECKLIST

TM 01/02.01 General Provisions

A. $\quad$ Purpose of Chapter

1. The purpose of this chapter is to provide a check list of procedures and events which should occur between the issuing of a death warrant and 24 hours prior to the execution.

2. Full detail will not be provided for each procedure or event in this chapter. For detail, reference will be made to Chapter TM 01/05 and other chapters where such detail may be found.

3. This chapter will be divided to cover the following time periods :

a. Receipt of death warrant to 30 days prior to the execution;

b. 29 to 14 days prior to the execution;

c. 13 to 7 days prior to the execution;

d. 6 to 3 days prior to the execution; and

e. 48 to 24 hours prior to the execution.

B. $\quad$ Policies

1. It is the policy of the Montana state Prison that the countdown to the execution be completed in a systematic and timely manner to ensure that all procedures and events which are necessary in the preparation of the execution are completed.

2. This countdown, though offering flexible application, should be observed and followed as written unless deviation or adjustment is required to meet the needs of the institution in carrying out the execution.

TM 01/02.02 Receipt of Death Warrant to Thirty Days Prior to Execution

Upon receipt of a death warrant from a competent court, the following procedures shall be initiated and should be completed at least 30 days prior to execution. 
A. Receipt of Death Warrant

1. Upon receipt of the death warrant, and as soon as practical thereafter, the Warden or designee will schedule a meeting with appropriate staff to develop assignments and coordinate the implementation of the procedures set forth in this technical manual.

2. The Warden or designee and selected staff will:

a. review the Execution Technical Manual (TM 01) and make any necessary revisions;

b. make assignments for the pending execution;

c. develop a schedule of events; and

d. take any other steps necessary to begin the execution countdown.

B. Time and Place of Execution

1. Date

The date for the execution shall be that day set by the sentencing judge.

2. Time and Location

The execution shall be performed within the double or single-fenced area of Montana state Prison anytime after midnight on the day set for execution by the court. It shall be performed in an area which is observable only by approved persons.

C. Condemned Inmate's Choice of Witnesses

1. The condemned inmate shall be informed that he may designate three people to witness the execution.

2. Refer to TM 01/07.

D. Disposition of Personal Property

1. The inmate shall be contacted for instructions concerning the disposition of his personal property.

2. Refer to TM 01/05.05.

E. Disposition of Funds in Inmate's Account 
1. The condemned shall be contacted for instructions concerning the disposition of the funds in any accounts controlled or administered by the prison.

2. Refer to TM 01/05.06.

F. $\quad$ Disposition of Body

1. The condemned shall be asked for instructions concerning the disposition of his remains following the execution.

2. Refer to TM 01/05.07.

G. Designate Persons Required to Assist with Execution

1. Those persons necessary to carry out the execution shall be identified.

a. The Warden or designee shall be responsible for identifying, selecting and obtaining the services of the Executioners. See TM 01/05.03 and TM 01/05.04

b. The Public Information Officer shall be responsible for coordinating the notification of the news media and those selected as news media witnesses. See TM $01 / 08.02$

c. The Warden or designee shall be responsible for selection of persons involved in perimeter security, crowd control, escort/ transportation, command post and access screening.

d. The Qualified Person performing the consciousness check procedures of TM 01/05.12G.2. f. and $\mathrm{g}$.

e.. The Warden or designee shall be responsible for designating those other persons necessary to carry out the execution, provide support functions during the execution and provide backup. In addition, the Warden or designee will contact outside law enforcement agencies to arrange for their assistance during the execution.

2. Redundancy in assignment shall be developed for vital or important positions. The Warden or designee shall determine which positions require backup and shall ensure adequate coverage is provided. 
H. Other Approved Witnesses

1. The Warden or designee in consultation with the Director shall approve witnesses as outlined in TM 01/07.03.

2. Refer to TM 01/05.04 for procedures for processing such requests.

I. Contact with Coroner

1. The Warden or designee shall contact the Coroner to coordinate the Coroner's role.

2. The Coroner shall be requested to provide direction concerning:

a. transfer of custody of the executed inmate from the Warden or designee to the Coroner;

b. transportation of the body from the execution site to the Coroner's facility; and

c. security arrangements during the transfer. These arrangements will be coordinated by the Warden or designee.

3. The Coroner may be contacted to act in making the pronouncement of death.

4. Refer to TM 01/05.04 and TM 01/02.

J. $\quad$ Support Services

1. The Warden or designee shall designate and notify a staff member to coordinate the functions of treatment and support services.

2. Support Services units shall include, but not be limited to:

a. the Infirmary (see TM 01/05. 14);

b. the Food Services Department (See TM 01/05. 14);

c. the Maintenance Department (See TM 01/05. 14); and

d. The Critical Incident Stress Debriefing (CISD) Team (see TM 01/05. 14)

e. Ranch/MCE Staging Area;

f. Doc Training Center. 
K. $\quad$ Prison Operations

a. It is necessary to maintain, as nearly as possible, a normal prison operation during the execution and during the pre- and post-execution period.

b. Briefings will begin as soon as plans evolve which will affect the general prison population, and will be scheduled until the operation returns to normal.

L. Day room and Yard Privileges

1. Upon receipt of the death warrant the condemned inmate's housing location and privileges will be reviewed and determined by the Warden or designee.

2. If the condemned inmate has Day room privileges, he will be required to have Day room alone. If at any time prior to the execution, the condemned inmate's conduct becomes inappropriate, Day room privileges will be suspended.

3. Upon receipt of death warrant, the condemned inmate will be required to go to yard alone, provided he does not abuse the privilege. If at any time prior to the execution, the condemned inmate's conduct becomes inappropriate, yard privileges will be suspended.

TM 01/02.03 Twenty-Nine to Fourteen Days Prior to the Execution

A. Witnesses

1. The Warden or designee shall develop a final list of witnesses consistent with the requirements of state statute (46-19-103 6B, MCA) and the Department of Corrections policy (DOC 3.6.1). Background checks shall be made on witnesses as deemed necessary.

2. Refer to TM 01/07.

B. News Media

1. Media Witness requests shall be received and processed by the Warden or designee in accordance with TM 01/08.02.

2. Alternate coverage/accommodations for members of the press selected to be present at the media staging area shall be handled consistent with TM 01/08.03. 
3. Any information provided to the media must be authorized in advance by the Warden or designee.

C. Inmate Property and Accounts

1. Finalize arrangements for disposition of the condemned inmate's property and accounts 14 days prior to execution.

2. Refer to TM 01/05.05.

D. Disposition of Body

1. Finalize, if possible, decision concerning disposition of the body.

2. Refer to TM 01/05.07.

E. Selection of Executioners

1. Finalize the selection of Executioners and their backups.

2. Refer to TM 01/05.03 and MT 01/05.04.

F. Medical/Medical Examiner

1. Finalize arrangements with Medical Examiner and Powell County Coroner for disposition of the body, security for the coroner's vehicle, and transfer of custody of the body.

2. Refer to TM 01/05.07, and TM 01/04.

G. $\quad$ Practices and Rehearsals

1. Initiate practice sessions for persons involved in the various parts of the execution event.

2. Not all the persons involved will practice together. Individual teams will practice as units, with inter-team practices scheduled as necessary to facilitate coordination and smooth interaction.

TM 01/02.04 Thirteen to Seven Days Prior to Execution

A. Inmate Property/Accounts

All paperwork on disposition of property and accounts should be completed at least seven days prior to the execution. 
B. Disposition of Body

All paperwork should be completed at least 14 days prior to the execution.

C. $\quad$ Food Services

1. At least seven days prior to execution, contact the condemned inmate to arrange for last meal. TM 01/05.14.

2. Determine with the Warden or designee and Public Information officer what coffee and food service will be needed at the various locations where staff will be working, and at the witness and news media staging areas.

D. Purchase of Substances to Be Used in Lethal Injection

1. Purchase substances to be used in the execution.

2. Refer to TM 01/05.12.

E. $\quad$ Support Services

Finalize all arrangements involving treatment and support services with the Warden or designee.

F. Enforcement and Investigations Coordination

1. The Warden or designee shall arrange a meeting to review the interaction between execution and security personnel and those assigned to the Special Response Team.

2. Joint rehearsal and practices should be conducted to ensure coordination and interaction is well-defined and understood.

G. Allied Agencies

Finalize arrangements with allied agencies assisting with the execution.

TM 01/02.05 Six to Three days Prior to Execution

A. Witnesses

1. A final list of approved execution witnesses will be provided/issued by the Warden or designee.

B. Brief Allied Agencies

1. Members of allied agencies who have not participated in 
practice sessions, or have not otherwise been briefed previously, shall be briefed and their posts or responsibilities explained.

2. Briefings will include a detailed review of the individual's post order.

3. A briefing will be conducted with the Director of DOC.

C. Inmate Property and Accounts

1. Complete all unfinished paperwork and arrangements.

2. If the condemned fails to cooperate in these arrangements, he shall be notified that the property and money will be disposed of according to prison policy.

D. Executioners

The Warden or designee shall:

1. verify arrangements for transportation and escort of the Executioner and his/her backup; and

2. ensure completion of all arrangements necessary for security of Executioners and protection of their identities.

E. Equipment Check/Inventory

1. As assigned by the Warden or designee, the equipment necessary to conduct the execution shall be inventoried and checked 72 hours prior to the execution.

2. Refer to TM 01/05.11.

TM 01/02.06 Twenty-Four to Forty-Eight Hours

A. Death Watch

1. The Warden or designee will determine the appropriate time to move the condemned inmate to the pre-execution cell but in no case later than 0800 hours on the morning prior to the scheduled execution.

2. The condemned inmate shall be under constant, close surveillance by staff members who shall observe and log all of the inmate's actions. 
3. Refer to TM 01/05.10.

B. Review of Execution Preparations

The Warden or designee, and appropriate staff shall meet to examine the preparations for the execution. The check lists shall be reviewed and immediate assignments made to bring all items current with the schedule of events.

C. $\quad$ Practice and Rehearsals

Conduct final practices and rehearsals.

D. Arrangements for Pickup of Executioners

1. The Warden or designee shall make final arrangements with the Executioners and their driver/escorts to coordinate their pickup and delivery to the Execution Chamber.

2. The pickup arrangements shall be known only to the Warden or designee.

E. Food Services

1. Verify last meal preparation.

2. Verify coffee/snack preparations for working teams, witnesses and the news media.

F. Communications

1. Verify installation of and test communications equipment for:

a. Execution Chamber, and

b. Warden or designee's Office.

2. Refer to TM 01/06.

G. Contact Support Services

1. Contact:
a. Governor's Office;
b. the Attorney General's Office
c. the State Medical Examiner's Office and Powell County Coroner; 
d. allied law enforcement agencies; and

2. Verify that each agency fully understands its role and is prepared to complete tasks.

H. Equipment Check

1. Review of execution chamber for readiness. 
TM $\quad 01 / 03.00 \quad$ EXECUTION CHECKLIST

TM $\quad 01 / 03.01$ General Provisions

TM 01/03.02 Twenty-Four Hours to Twelve hours Prior to Execution

TM 01/03.03 Twelve Hours to Six hours Prior to Execution

TM 01/03.04 Six Hours to Three Hours Prior to Execution

TM 01/03.05 Three Hours to Thirty Minutes Prior to Execution

TM 01/03.06 Final Twenty-Nine Minutes 
TM $01 / 03.00$

TM 01/03.01 General Provisions

\section{A. $\quad$ Purpose of Chapter}

1. The purpose of this chapter is to provide a checklist of procedures and events which should occur the final 24 hours prior to the execution.

2. Full detail will not be provided for each procedure or event in this chapter. For detail, reference will be made to Chapter TM 01/05 and other chapters where such detail may be found.

B. $\quad \underline{\text { Policy }}$

1. It is the policy of Montana state Prison that the countdown to the execution be completed in a systematic manner to ensure that all procedures and events necessary to carry out the execution are carefully coordinated and completed.

2. The execution shall be carried out in a manner consistent with state law.

TM 01/03.02 Twenty-Four Hours to Twelve Hours Prior to Execution

1. Refer to TM 01/05.13.

A. Inmate Property and Cell

1. The inmate's cell shall be searched, and his property inventoried and removed when moved to the pre-execution cell.

2. Refer to TM 01/05.13.

B. Inmate Communication

1. The condemned inmate's telephone privileges shall be terminated at 1500 hours on the day preceding the execution.

2. Visiting shall be permitted until 1030 hours the day preceding the execution with immediate family:

a. With restrictions on the number of visitors and type of visit (contact/non-contact) decided on a case-by-case basis.

3. The condemned inmate's religious representative and attorney shall also be given liberal visiting privileges during the 
final 24 hours. Visiting privileges shall be suspended when preparations for the execution require such suspension.

4. This section will be reviewed with security staff prior to each execution. Additional restrictions may be imposed by the Warden or designee as deemed necessary.

5. Refer to TM 01/05.10.

C. Food Services

1. The Food Services Director shall contact the condemned to make arrangements for the final meal.

2. The final meal shall be served between 1700 and 2000 hours.

3. Refer to TM 01/05.14.

D. Access to Maximum Security

1. Twenty-four hours prior to the execution, access to the Maximum Security Building shall be restricted to:

a. on-duty staff specifically assigned to Maximum Security;

b. execution preparation staff;

c. those other staff required to carry out Maximum Security operations; and

d. others approved by the Warden or designee.

2. Refer to TM 01/10.

E. Equipment Check

1. At least 24 hours prior to the execution, equipment shall be inventoried and tested.

2. Refer to TM 01/05.08 and TM 01/05.11.

TM 01/03.03 Twelve to Six Hours Prior to Execution

A. Final Briefing

1. Special teams shall be assembled approximately 12 hours prior to the execution.

2. The final briefing will be attended by personnel identified 
by the Warden or designee.

3. During the briefing, participants shall:

a. identify problems, develop solutions and specify time lines;

b. provide status reports;

c. coordinate support services involvement; and

d. conduct final walk-through of procedures.

B. Food Services

1. The condemned shall be fed lunch between 1030 and 1300 hours.

2. The final meal shall be served between 1700 and 2000 hours.

C. Visits

1. Personal visits shall be terminated at 1030 hours.

2. Visits with the inmate's religious representative and attorney may be permitted until final preparations require suspension of visits.

D. Restricting Access to Prison Property

1. During the final 24 hours, access to prison property shall be limited to:

a. on-duty staff;

b. construction workers;

c. necessary volunteers;

d. approved delivery vehicles;

e. law enforcement personnel on business-related matters;

f. approved Department of Corrections staff;

9. other persons approved on a case-by-case basis to be on site; and

h. visitation only for the condemned inmate.

2. During the final eight hours:

a. all visitors shall be required to leave prison property; 
b. all off-duty personnel shall be required to leave prison property;

c. all persons entering prison property shall be required:

1. to have an execution pass properly coded for entry and be on the Master Security Pass List; or

2. if on-duty and in uniform, be wearing a prison ID badge and be on the Master Security Pass List.

d. all deliveries shall be turned away.

e. all construction workers shall be required to exit the site, unless listed on the Master Pass List.

E. Access to Maximum Security

1. During the final eight hours, access to Maximum Security shall be restricted and limited to:

a. on-duty staff specifically assigned to Maximum Security;

b. execution preparation staff;

c. those other staff required to carry out Maximum Security operation; and

d. others approved by the Warden or designee.

2. All access to the designated Execution Chamber during the final eight hours will be restricted to staff and others wearing an appropriately coded security pass.

TM 01/03.04 Six to Three Hours Prior to Execution

A. Delivery of Lethal Injection Drugs to the Warden or designee

1. The drugs used in the lethal injection shall be picked up from their storage location by the Warden or designee six hours prior to the execution and delivered to the pharmacist.

2. After the syringes are prepared by the pharmacist, the Warden or designee shall maintain custody of the drug boxes until he surrenders them to the setup officer. 
A. $\quad$ Pre-Execution Procedures

1. The Warden or designee shall ensure that all countdown procedures for all required activities and actions are completed.

2. Immediate action to complete any unfinished required procedures shall be initiated.

B. Execution Site Teams Assemble

1. All execution site teams shall be assembled (except for the Executioners) for final instructions at least one hour prior to the execution.

2. The Tie-Down Teams and their backups will be positioned to await escort of the condemned to the execution site.

C. Contact with the Attorney General's Office

1. Two hours prior to the scheduled time of execution the Warden or designee shall open a line with the Attorney General's Office.

a. The Warden or designee shall make initial contact and determine the status of the execution at that point.

b. After initial contact is made, the Warden or designee shall monitor the line.

2. Absent an instruction to halt the execution, per established protocol with the Governor's Office, the execution will proceed as planned.

3. The Attorney General's Office or Governor's Office shall be the only sources from which stays, commutations or other delays may be received.

TM 01/03.06 Final Twenty-Nine Minutes Prior to Execution

A. Communications with Attorney General's/Governor's Office

1. Twenty-five minutes prior to the execution, the Warden or designee will leave the Office and proceed to the Execution Chamber to monitor the line connecting the execution site with the Attorney General's Office. Refer to TM 01/03.05, c, above. 
1. Bringing Condemned Inmate to Execution Site

The condemned inmate shall be:

a. removed from the holding cell by the Tie-Down Team;

b. strip-searched by the Tie-Down Team and then dressed in a clean, orange, short-sleeve jump suit;

c. secured with handcuffs and leg irons; and

d. escorted to the execution site.

2. Tie-Down Procedures

At the execution site, the restraints shall be removed and the condemned shall be tied down as explained in TM 01/05.14.

3. Prepare Condemned Inmate for Execution

The condemned shall be readied for execution:

a. By lethal injection, by completing the I.V. setup procedure (See TM 01/05.11).

4. Admit Witnesses

a. Witnesses shall be admitted and escorted to viewing areas.

b. The state witnesses shall be seated first.

c The next witnesses to be seated shall be the authorized witnesses invited by the condemned.

d The next witnesses to be admitted shall be victims witnesses.

e. The final witnesses to be seated shall be the news media.

C. Final Sequence of Events: Execution

1. Staff Witness

a. Staff participating in the preparation for the execution shall exit the execution site.

b. Staff members authorized to participate and observe may include the: 
1. Warden;

2. Associate Wardens as assigned;

3. Security tie-down team;

4. Public Information Officers;

5. Log/Recorder; and

6. Director/DOC.

\section{Countdown}

a. When the witnesses are in place and everything is ready, the Warden or designee shall give word to proceed.

b. The Warden or designee will address the condemned with a pre-prepared statement to include:

Official name of condemned, time and place to carry out the order of the court, and condemned's desire to make a last statement.

(1) The inmate statement should not exceed two minutes.

(2) If the statement exceeds two minutes, the execution shall proceed without waiting for the conclusion of his remarks.

c. At the conclusion of the remarks, or when the Warden or designee determines it is time to proceed after verifying the earliest legal execution time has passed, he shall announce, "We are ready." A pre-arranged signal shall then be given by the Warden or designee to the Executioner to proceed.

d. The Executioner shall commence the execution upon receiving the Warden or designee's signal;

e. Following the instruction from the Warden or designee to execute the condemned inmate, the Executioner shall immediately proceed with the execution as required in TM 01/05.12.

f. If the execution is ordered delayed by the Attorney General's Office or the Governor's Office to the Warden's designee on the telephone, he shall notify the executioner/s that the execution has been stayed or delayed. The procedures set forth under TM 01/06 shall 
then be initiated. 


$\begin{array}{ll}\text { TM 01/04.00 } & \text { POST-EXECUTION PROCEDURES } \\ \text { TM 01/04.01 } & \text { General Provisions } \\ \text { TM 01/04.02 } & \text { Certification of Death } \\ \text { TM 01/04.03 } & \text { Removing Witnesses from Execution Chamber } \\ \text { TM } 01 / 04.04 & \text { Removal of Executed Inmate } \\ \text { TM } 01 / 04.05 & \text { Removing Executioners from the Execution Area } \\ \text { TM } 01 / 04.06 & \text { Site Clean-Up } \\ \text { TM } 01 / 04.07 & \text { Returning to Standard Operation } \\ \text { TM 01/04.08 } & \text { Dismantling the Execution Chamber } \\ \text { TM 01/04.09 } & \text { Staff Debriefing } \\ \text { TM 01/04.10 } & \text { Returning of the Death Warrant }\end{array}$


TM $01 / 04.00$

POST-EXECUTION PROCEDURES

TM 01/04.01 General Provisions

A. $\quad$ Purpose of Chapter

The purpose of this chapter is:

1. to provide the procedures to be carried out following the death by execution of the condemned inmate;

2. to identify the responsibilities for tasks to be completed; and

3. to provide for the transfer of the body of the condemned.

B. $\quad \underline{\text { Policy }}$

It is the policy of Montana state Prison that:

1. the condemned inmate shall be examined by a qualified official following the administration of the lethal drugs to ensure that death has occurred;

2. the qualified official when satisfied that death has occurred, shall certify the condemned inmate is dead;

3. the witnesses to the execution shall be removed from the Execution Chamber and returned to the staging area. A Critical Incident Stress Debriefing (CISD) will occur at a designated location prior to witnesses leaving the facility;

4. following pronouncement of death, the body of the condemned shall be surrendered to the Powell County Coroner;

5. the prison shall deactivate and evacuate from Montana state Prison property those who have assisted in the execution process; and

6. the entire execution process shall be evaluated by Montana State Prison staff and others involved to permit a post-execution examination of the competence, efficiency and effectiveness of the execution procedures and staff.

TM 01/04.02 Certification of Death

A. After the drugs have been administered:

1. the Warden or designee will wait a minimum of one minute and 
then signal the qualified official to take the condemned's vital signs.

2. the qualified official shall take the condemned's vital signs.

B. If there are signs of life, the qualified official shall wait beside the gurney and check the vital signs every 60 seconds until vital signs cease.

C. The qualified official shall then certify death according to accepted medical standards.

TM 01/04.03 Removing Witnesses from Execution Chamber

A. After the pronouncement of death by the physician, the witnesses shall be escorted from the chamber in the following order:

1. media witnesses;

2. victim witnesses;

3. condemned inmate's witnesses;

4. state witnesses.

B. All witnesses shall be escorted back to the waiting area, with the exception of news media witnesses who will be taken to the media staging area to brief the other members of the media.

TM 01/04.04 Removal of Executed Inmate

A. After the witnesses have been removed:

1. the IV lines and tubes shall remain intact, and along with the syringes used, be transported with the inmate's body to the state crime lab, or county morgue whichever is appropriate.

2. the restraints removed from the inmate's body by the Tie-Down Team.

3. the Coroner will obtain the necessary body fluid/serum samples in accordance with the stipulations set forth by the State Medical Examiner.

B. The State Medical Examiner and Powell County Coroner will supervise removal of the body and placement in the Coroner's vehicle for transportation. 
A. After the witnesses have been escorted from the execution site, the area between the Executioners' station and the Executioners' transport vehicle shall be cleared of staff and other persons.

B. When the area is secure, the Executioners shall be escorted to the Executioners' transport vehicle by the Warden's designee.

C. The Executioners shall remain in the transportation vehicle until they are driven back to the designated location for pickup/drop off.

TM 01/04.06 Site Clean-Up

A. The person responsible for injection duties shall:

1. gather all used and unused medications, syringes, etc.;

2. place the gathered items in the lethal injection drug box;

3. close and place a seal on the drug box; and

4. surrender the box to the Correctional Investigator.

B. The Tie-Down Team shall be responsible for assisting the Coroner in preparing the body for transport.

C. The Montana State Prison Maintenance Department shall, at a time directed by the Warden or designee, restore the Execution Chamber to its original condition.

TM 01/04.07 Returning to Standard Operation

A. Following the execution, Montana state Prison and involved agencies shall be deactivated as appropriate under the direction of Warden or designee.

B. The Execution Chamber shall be locked and secured when the Warden or designee is satisfied that use of the building interior has been completed.

C. The Operations Security Chief shall determine when to secure the media staging areas.

D. The Associate Warden of Security or designee shall be responsible for bringing perimeter security back to standard operation. 
A. The Montana State Prison Maintenance Department shall, at a time directed by the Warden or designee, restore the Execution Chamber to its original condition and location.

TM 01/04.09 Staff Debriefing

A. A diffusing session will be held in the RAC for the Tie Down Team members, Escort Officers, Death Watch Staff, and any other department staff directly involved in the execution. It shall be mandatory that involved staff attend the diffusing session.

B. A debriefing session will be conducted within five days after the execution for those staff directly involved in the execution. It shall be mandatory that staff directly involved attend the debriefing.

C. A volunteer informal meeting for general staff will also be scheduled, to address any staff issues.

TM 01/04.10 Returning of the Death Warrant

A. Within 20 days after the execution, the Warden or designee will return the death warrant to the clerk of the Trial Court from which it was issued, along with the log required within this instruction. 


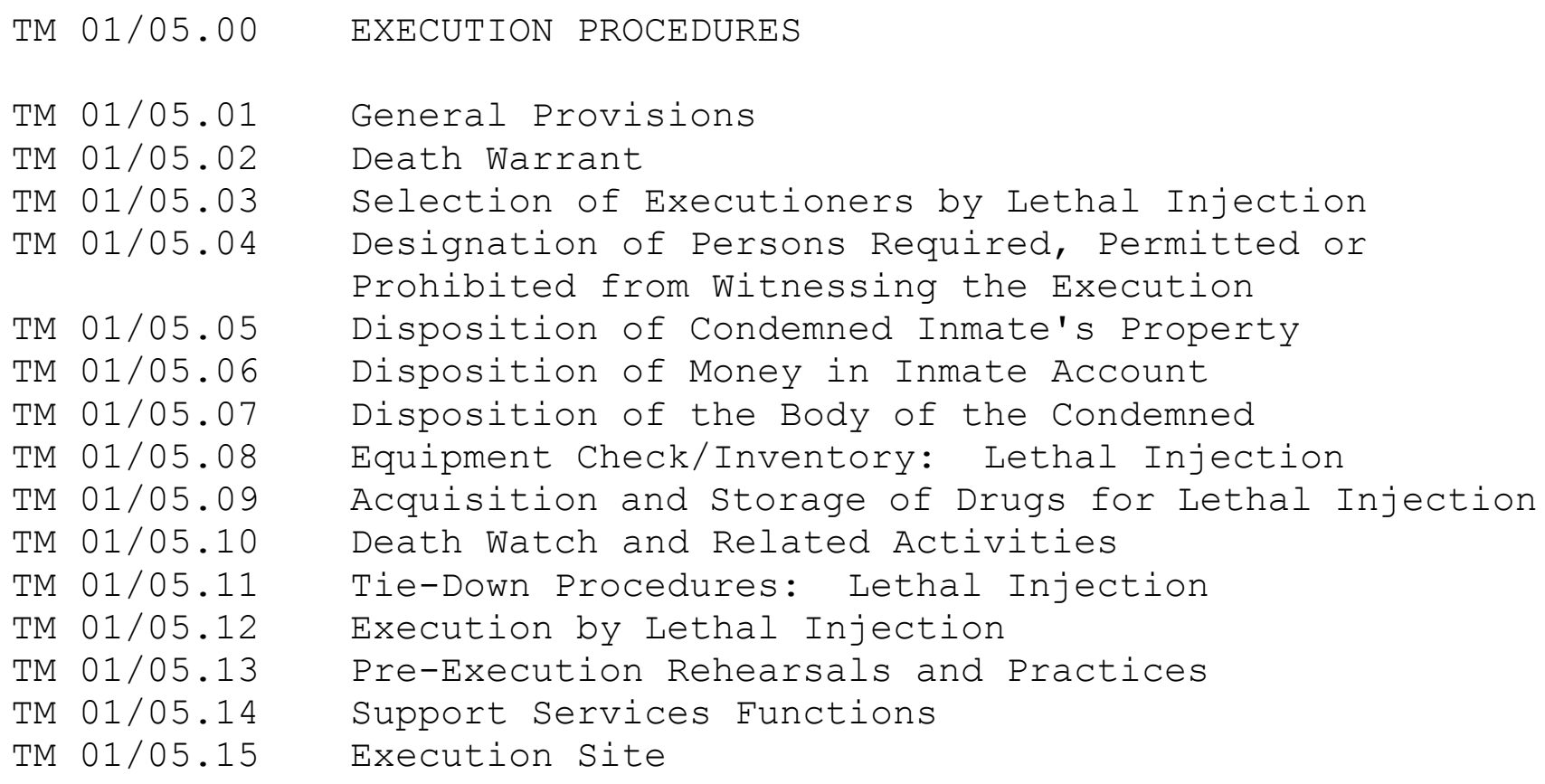

Execution Site

TM $01 / 05.14$

TM $01 / 05.15$ 
TM 01/05.00 EXECUTION PROCEDURES

TM 01/05.01 General Provisions

A. Purpose of Chapter

1. This chapter provides the procedures which are used when the prison exercises its statutory responsibility to carry out an execution.

2. The topics include those procedures which are employed:

a. from receipt of the death warrant to and during the execution;

b. immediately following the execution; and

c. during the debriefing and audit phases of the execution.

B. Policy

1. It is the policy of Montana state Prison that the procedures employed in preparing for and carrying out an execution be comprehensive and clearly defined.

2. The procedures shall be developed consistent with state and federal law.

TM 01/05.02 Death Warrant

A. Commitment of Defendant

When a judgment of death is rendered, and pending execution of a sentence of death, the sheriff may deliver the defendant to the state prison for confinement, and the state shall bear the costs of imprisoning the defendant from the date of delivery until execution. MCA 46-19-101 and 46-19-103.

B. Return Upon Death Warrant

1. Following the execution, the death warrant shall be completed by the Powell County Coroner. The warrant shall contain the signature of the qualified official pronouncing death and of the Warden or designee, and shall indicate the time and manner of death.

2. The Warden or designee shall send the death warrant to the sentencing court and retain a copy for the prison file. 
A. Statutory Requirements

1. An execution carried out by lethal injection must be performed by a person selected by the Warden or designee and trained to administer the injection. The person administering the injection need not be a physician, registered nurse or licensed practical nurse licensed under the laws of Montana or any other state. MCA 46-19-103(5).

2. The Warden or designee shall select the person to perform the execution, and the Warden or designee shall supervise the execution.

B. $\quad$ Method of Selection

Department of Corrections Policy 3.6.1 sets out the requirements for selection of Executioners for lethal injection.

1. The Executioner shall be chosen by the Warden or designee from among those prison employees, or non-prison employees, who volunteer for the duties of the Executioner. Executioner could also be a contract employee.

2. The Warden or designee shall also select an alternate Executioner, or if there are no volunteers available, the Warden or designee shall perform the execution.

3. The Warden or designee shall provide training to the Executioner, the alternate Executioner, and other staff as required. Training at a minimum to include: Proper needle placement, syringe process, proper method of administering drugs and saline flush, identification of problems with drugs not going into a vein (infiltrated IV line) and responsibilities and protocol for the Executioner.

4. The identity of the Executioner and alternate Executioner shall remain confidential.

C. Securing Services

1. The Warden or designee shall contact those chosen for the position of Executioner and alternate Executioner to notify them of their selection and to verify their willingness and availability to perform the duties of execution by injection.

2. If any person rescinds his original offer to participate, the Warden or designee will select a replacement. 
A. Montana Code (46-19-103 6b MCA) and Department of Corrections policy (DOC 3.6.1) limits and identifies those persons who may attend and witness the execution, reference TM 01/07.

B. The Warden or designee shall designate the required personnel from Montana State Prison staff to carry out the statutory requirements of an execution. Staff shall include:

1. Warden or designee;

2. Associate Warden (s);

3. Death Watch Officers (3);

4. Tie-down Officers (6), including a team of four officers and two alternates;

5. Executioners; reference TM 01/05.03;

6. Escort Officers (2-3) .

C. The Warden or designee shall designate personnel necessary to carry out the requirements of an execution including:

1. Designated Certified Medical Personnel, responsible for advising the Warden or designee concerning any medical supplies, etc.;

2. Food Service Manager, responsible for the preparation and supervision of meals prepared during the death watch, and for the condemned inmate's last meal;

3. Maintenance Services Manager, responsible for equipment inventory, check and maintenance of all facilities used during the execution, as well as stand-by fire crew.

4. A designated pharmaceutical company responsible for ordering, verifying, picking up the drugs, equipment, etc., necessary to carry out an execution by lethal injection;

5. A qualified official, responsible for pronouncing the death of the condemned inmate.

TM 01/05.05 Disposition of Condemned Inmate's Property

A. Contact with Condemned Inmate 
1. At least 30 days prior to the scheduled execution the condemned inmate should be contacted to discuss arrangements for disposing of his property.

2. At least 14 days prior to the execution property-disposition arrangements should be finalized.

3. At least seven days prior to the execution all paperwork required for final disposition should be completed.

4. If the condemned is uncooperative, doesn't wish to make specific property-disposition arrangements, or for any other reason has not made arrangements for disposition, he shall be notified the property will be disposed of as required.

B. Options for Disposing of Property

1. Property may be released to an authorized visitor (family, friend or attorney). The release would follow the normal property release procedures.

2. Property may be mailed through the U.S. Postal Service. Montana State Prison's Mail Department shall process the mailing consistent with standard mail procedures. Indigent status does not cover property-release postage.

3. Property may be donated to a charitable organization.

4. The property must be picked up or mailed out within 60 days. After 60 days, Montana State Prison is no longer responsible for property and it will be disposed of consistent with policy

5. Absent directions from the condemned, property will be disposed of as contraband.

C. Release Procedure

1. Following a decision to release the condemned's property, the property shall be:

a. inventoried by the Property Officer; and

b. transferred to the property room.

2. The release will then follow according to the appropriate release procedures.

TM 01/05.06 Disposition of Money in Inmate Account

A. Contact with Condemned Inmate 
Follow the timetable for contact with the condemned outlined for property under TM 01/05.05.

B. Options for Disposing of Inmate Accounts

1. The condemned shall be required to complete a money transfer form releasing the money in his account to his next of kin or other person or organization of his choice.

2. If the condemned refuses or otherwise fails to complete the necessary forms, the funds shall be disposed of consistent with Montana state Prison policy and state law.

TM 01/05.07 Disposition of the Body of the Condemned

A. Release to Medical Examiner

1. After the executed inmate is pronounced dead, the body shall be released from the restraints and removed from the execution site.

2. The body shall be immediately surrendered to the state Medical Examiner and Powell County Coroner. The Medical Examiner/Powell County Coroner will then be responsible for removing the body from the prison for autopsy and, if appropriate, organ donation.

B. Release for Burial

1. The body of the executed inmate shall be released to the next of kin or other persons designated for funeral preparations no later than 24 hours after the arrival at the office of the Medical Examiner.

2. If the condemned inmate fails to designate persons to claim the body or make other arrangements, the body will then be disposed of as directed by state statute.

TM 01/05.08 Equipment Check/Inventory: Lethal Injection

\section{A. Responsibility}

1. The Designated Staff Person shall conduct a check of equipment and materials necessary to conduct the execution. The Designated Staff Person will review and ensure that expiration and/or sterilization dates have not been exceeded. 
2. The inventory shall be conducted 72 hours prior to the execution.

\section{B. Inventory}

1. An inventory checklist shall be completed, dated and initialed by a Designated Staff Person based on the established inventory form. Items marked "A" in the "code" column of the inventory check list shall be carried into the Execution Chamber by the Warden or designee within $1 \frac{1}{2}$ hours of the execution and turned over to the set up personnel and the Executioner. (Attachment A) 
Execution Equipment and Material Checklist: Execution by Injection

\begin{tabular}{|c|c|c|}
\hline Numbe & ITEM & CODE \\
\hline 6 & Sodium Pentothal, $1 \mathrm{gm}$. kit, $(50 \mathrm{mg} / \mathrm{ml})$ * & A \\
\hline 20 & Pancuronium Bromide, $10 \mathrm{mg} / 5 \mathrm{ml} \mathrm{vial} *$ & A \\
\hline 3 & Diazepam (Valium), $2 \mathrm{ml}$ Dosette syringe & A \\
\hline 20 & Syringe, 60 cc Lur Lock & $\mathrm{B}$ \\
\hline 10 & Syringe, 10 cc Lur Lock & $\mathrm{B}$ \\
\hline 10 & Syringe, 5 cc Lur Lock & $\mathrm{B}$ \\
\hline 40 & $18 \mathrm{Ga} ., 1$ 1/2" needles & $\mathrm{B}$ \\
\hline 20 & $25 \mathrm{Ga} ., 1$ 1/2" needles & $\mathrm{B}$ \\
\hline 50 & $14 \mathrm{Ga} ., 1$ 1/4" angiocath & $\mathrm{B}$ \\
\hline 50 & $16 \mathrm{Ga} ., 1$ 1/4" angiocath & $\mathrm{B}$ \\
\hline 50 & $18 \mathrm{Ga} ., 1$ 1/4" angiocath & $\mathrm{B}$ \\
\hline 8 & Normal Saline, IV bag, 1000 cC & $\mathrm{B}$ \\
\hline 8 & Solution Injection set; 106" long with Y sites & B \\
\hline 16 & Extension set, 35" & $\mathrm{B}$ \\
\hline 2 & Stethoscopes & $\mathrm{B}$ \\
\hline 3 & Boxes of alcohol preps & $\mathrm{B}$ \\
\hline 24 & Rolls of Kling & B \\
\hline 4 & $1^{\prime \prime}$ adhesive tape, & $\mathrm{B}$ \\
\hline 4 & 2" adhesive tape, & $\mathrm{B}$ \\
\hline 3 pr & Bandage scissors & $\mathrm{B}$ \\
\hline 12 & IV start Kits (gauze, dressing, CloraPrep, tape, tourniquet) & B \\
\hline 3 pr & Surgical gloves size 7 1/2, (sterile) & $\mathrm{B}$ \\
\hline 3 pr & Surgical gloves size 8 (sterile) & $\mathrm{B}$ \\
\hline & Box Gloves, 100 Large (nonsterile) & B \\
\hline 12 & Surgical masks & $\mathrm{B}$ \\
\hline 3 pr & Hemostats & B \\
\hline 6 & $3^{\prime \prime}$ ace wraps & $\mathrm{B}$ \\
\hline 100 & Gauze pads (sterile) & B \\
\hline 1 & Clean up kit & $\mathrm{B}$ \\
\hline 1 & Flashlight with batteries & $\mathrm{B}$ \\
\hline 6 & Batteries (flashlight spares) & B \\
\hline 1 & Tourniquet & $\mathrm{B}$ \\
\hline 1 & Large Sharps container & B \\
\hline 2 & Small Sharps container & $\mathrm{B}$ \\
\hline
\end{tabular}

* Drugs listed may be substituted with another equivalent type drug if drug listed becomes unavailable. Refer to TM 1/05.12 E4 
2. At least one hour prior to the execution, the Executioner shall enter the Execution Chamber, take receipt of the inventory items noted with " $A$ " in the inventory column and re-inventory the remaining supplies and equipment to ensure that all is in readiness.

TM 01/05.09 Acquisition and Storage of Drugs for Lethal Injection

A. $\quad$ Purchase

1. Fourteen days prior to the scheduled execution, the Warden or designee shall provide to designated pharmaceutical company for their official records a memorandum specifying:

a. the drugs which must be obtained:

b. a copy of the judgment of death; and

c. a copy of the state statute. (MCA 46-19-103)

2. Seven days prior to the execution, designated pharmaceutical company will deliver the drugs to the Montana state Prison Infirmary. Upon taking custody of the drugs the Health Services Administrator or designee shall take receipt of the drugs, ensure drugs received are correct, and deliver all drugs to the Warden or designee.

a. the Warden or designee shall take receipt of the drugs from the Health Services Administrator or designee and shall verify the quantity, seals and expiration dates and immediately;

b. Shall place the drugs in a vault in the correctional Investigator's office, witnessed by a DOC Investigator.

B. Storage and Handling of Drugs

1. Three hours prior to the execution, the Warden or designee shall pick up the drugs from the Investigation Storage Vault.

2. The Warden or designee will ensure that all of the drugs are secured from the Investigations Unit and delivered to the designated site for syringe preparation by the contract Pharmacist. The Warden or designee shall witness the preparation of the syringes.

3. Within two hours of the execution time, the pharmacist shall prepare all syringes for the execution with one set of 
syringes identified as primary and one set as backup.

4. The drug boxes containing the syringes shall then be surrendered to the Warden or designee.

5. The Warden or designee shall retain the two (primary and backup) drug boxes until he transports them to the execution chamber for delivery to the Executioner and setup staff.

TM 01/05.10 Death Watch and Related Activities

A. $\quad$ Access

1. Access to the holding cell shall be limited to those persons whose presence is specifically required for purposes related to the preparation and implementation of the death watch.

2. The Warden or designee shall prepare a list of those having access to the holding cell area. The death-watch list shall be updated by the Warden or designee, as required.

3. Persons accessing the holding cell area shall have appropriate clearance for the area.

B. Preparation of the Pre-Execution or Holding Cell

1. $\underline{\text { Search }}$

a. The holding cell shall be carefully swept and cleaned prior to the search.

b. The holding cell shall be searched by a two-person team, one hour prior to the condemned inmate's move.

c. The Locked Housing Unit-I Unit Manager or designee shall search the cell after the search team is finished.

2. Stocking the Cell

a. The holding cell shall be outfitted with the following items :
(1) mattress (1);
(2) pillow (1);
(3) pillow case (1); 

(4) sheets (2);
(5) blankets (2);

b. If requested, the cell will also have the following items. Nothing from the previous cell except photographs and a Bible shall be transferred to the holding cell. The other items must be purchased new:
(1) Bible (1);
(2) magazine (one at a time);
(3) newspaper; and
(4) photographs.

c. The following items may be given on request, as needed, and must be returned immediately after use if not consumed:
(1) tooth brush (1);
(2) toothpaste (will be applied to brush by Death Watch officer); and
(3) battery operated electric shaver.

d. If the condemned inmate receives mail, the officer shall allow the condemned inmate approximately 15 minutes to read the mail.

e. The condemned inmate must surrender the correspondence immediately after reading .

f. Other items of personal property may be allowed at the discretion of the Warden or designee.

3. Test Equipment

a. Twenty-four hours prior to moving the condemned to the holding cell, all locks, lights, plumbing, etc., shall be checked to ensure they are in good working order.

b. One hour before the move, all systems shall be checked again.

C. Moving the Condemned to the Holding Cell

1. When administrative activities become disruptive to the 
routine of the cell block, or the condemned/inmates on the block become disruptive, the condemned shall be moved to the holding cell. In no case should this be done later than 0800 hours on the day prior to the scheduled execution.

2. Without warning or notice, and as directed by the Warden or designee, Death Watch Officers, with assistance of Maximum Security Unit staff, will inform the condemned inmate that he is moving and order the inmate to comply with a strip search.

3. Following the strip search, the condemned will be issued a short-sleeved jump suit and shower shoes to wear to the holding cell.

4. Once dressed, the inmate will be restrained in handcuffs, behind the back and be ordered to kneel, with feet to the cell door.

5. The cell door shall be opened; one officer shall hold the inmates arm to ensure control, while the other officer applies leg irons.

6. The condemned inmate will then be escorted to the holding cell and restraints removed using the same protocol in reverse order.

D. Securing Condemned Inmate's Property/Cell

1. Whenever possible, the inmate will make arrangements to pack and inventory his property with the Property officer prior to his move to the holding cell.

2. After transferring the condemned inmate to the holding cell, the two-person search team which searched the holding cell shall enter the cell from which the condemned was removed.

3. One member of the team shall search while the other member inventories and documents the search.

a. The searching member shall call out each item to be inventoried for the recording member of the team to log.

b. Each item secured shall be searched carefully for:

(1) contraband;

(2) indications of an escape plan; 
(3) indications of suicide plans; and

(4) other information which would indicate possible problems during the final hours leading to execution.

4. Personal property shall be separated from prison property, and the personal property put into a suitable container and sealed. Each search team member shall initial the seal.

5. The search team shall then reverse roles and the second member shall search the "clean" cell to attempt to discover anything missed in the first search.

6. The cell shall then be locked until ready for reassignment. Reassignment shall not occur for 48 hours after the execution, in case an additional search of the cell is required.

7. The personal property shall be taken to the property room for storage.

E. Death Watch Function

1. The Death Watch Officer shall constantly observe the condemned inmate, documenting significant activities on the death-watch log. Significant activities include but are not limited to:
a. eating;
b. reading;
c. visitors;
d. comments;
e. sleeping;
f. showers;
g. outbursts of anger, rage, etc.; and
h. suicide gestures or attempts.

2. The contents of the death-watch log shall be turned over to the Associate Warden of Security and made a part of the Records Office file upon completion of the execution. 
3. The death watch shall be a two-person team, with backup officer stationed away from, but in sight of, the death-watch team. The three shall change roles each hour. The Locked Housing Unit-I Unit Manager or designee may add his staff to the rotation at his discretion.

4. The death-watch team shall not enter the cell unless exigent circumstances require such entry, and then only after summoning the assistance of other officers. The other officer will notify the Locked Housing Unit-I Unit Manager. Exigent circumstances would include:
a. suicide attempts;
b. self-injury attempts; or
c. serious medical problems.

F. Activities During Death Watch

1. The chaplain approved by the Warden or designee may visit the inmate throughout the death watch, except that his visits shall not interrupt other necessary functions, nor be conducted in a manner that would jeopardize security and order.

2. Meal service, including the last meal, shall be served during the death watch. The last meal should be served between 1700 and 2000 hours on the day preceding the execution.

3. During the final 24 hours, the condemned may be provided with reasonable doses of a tranquilizer, at his request and on orders from a physician.

4. Telephone privileges shall be suspended at 1500 hours, unless authorized by the Warden or designee.

5. Visiting shall be permitted after the inmate is moved to death watch under the following conditions:

a. Visits shall be only with family.

b. All personal visits except clergy and attorney shall be terminated by 1030 hours on the day preceding the execution.

c. Attorney visits shall, however, be terminated in sufficient time to permit the preparation process during the final countdown. 
d. The number and type of visit (contact/non-contact) shall be decided on a case-by-case basis.

TM 01/05.11 Tie-Down Procedures: Lethal Injection

A. Transfer of Condemned Inmate to Execution Site

1. The condemned inmate shall be escorted from the holding cell to the execution site by the Tie-Down Team. The condemned inmate should arrive at the execution site 25 minutes prior to the scheduled time of the execution.

2. The Tie-Down Team shall be positioned as follows:

a. one officer directly in front of the condemned inmate;

b. two officers positioned on each side of the condemned inmate holding on to the condemned inmate's arm; and

c. one officer directly behind the condemned inmate.

B. Positioning of the Tie-Down Team

1. The Tie-Down Team shall be comprised of four members, and two alternates.

2. There shall be one Tie-Down Officer positioned on each side at the bottom of the gurney by the condemned inmate's feet.

3. There shall be one Tie-Down Officer positioned on each side by the condemned inmate's arms.

4. If the condemned becomes disruptive or faint he will be secured to the spine board as described in tie-down post orders.

C. Securing Inmate to Gurney

1. The condemned inmate shall be ordered to sit on the gurney. The Tie-Down Officers shall assist by lifting his feet in position on the gurney and assisting him to lie down.

2. The condemned inmate shall be strapped on the gurney as follows:

a. the condemned inmate's ankles and the strap across his chest shall be buckled down simultaneously by the 
Tie-Down Team.

b. one officer shall then release the restraints on the condemned inmate's hands, one at a time;

c. the officers positioned on each side of the condemned inmate's arms shall immediately secure the condemned inmate's wrists to the gurney;

d. the Tie-Down Team positioned at the condemned inmate's arms shall then place the strap across the abdomen, above the knees, and below the knees on the condemned inmate;

e. during the time the straps are being placed on the condemned inmate as outlined in "d." above the Tie-Down Officers positioned at the condemned inmate's feet shall remove the leg restraints and re-check to ensure the tie-down strap remains secure;

f. one officer shall inspect the straps to ensure they are secure; and

g. Shall inform the Warden or designee the condemned inmate is secured to the gurney;

h. Once the inmate is secured to the gurney, the Tie-Down team will move to their designated staging area. Two members of the Tie-Down Team will remain in chamber.

3. If the condemned inmate struggles or resists efforts to secure, the condemned inmate shall be secured as outlined in "C" above with the Tie-Down Team using force to secure the condemned inmate.

4. As directed by the Warden or designee, the Tie-Down Team shall exit the Execution Chamber and remain outside the Execution Chamber, but not in a position to witness the execution;

5. upon completion of the execution, and as directed by the Warden or designee, the Tie-Down Team shall enter the Execution Chamber and remove the straps in the reverse order as outlined above.

TM 01/05.12 Execution by Lethal Injection

A. At least one hour prior to the execution the Executioners and Setup Officer shall be escorted into the Execution Chamber by Warden's designee. 
B. The Executioner shall complete a pre-execution inventory and equipment check (reference TM 01/05.08); and

C. The Setup Officer shall prepare the IV set-up.

D. IV Set-Up Procedure

1. The connector of Administration set (Braun CSP 152 VSL or equivalent) shall be inserted into the bag of Normal Saline IV solution.

2. The flow of solution shall be controlled by the Flo-Trol clamp located above the "Y" site.

3. A 35-inch extension set (Braun SCE 33SL or equivalent) shall be connected to the needle adapter of the Administration set.

4. All connections should then be taped to ensure they do not come apart during the procedure.

5. The tubing shall be cleared of air by removing the protector from the needle adapter and opening the Flo-Trol clamp letting the tube fill with solution.

6. The Flo-Trol clamp shall then be closed and the protective cap over the needle adapter replaced.

7. Steps 1 through 6 shall be repeated for the second set-up.

E. $\quad$ Preparation of Syringes

1. Two hours prior to the execution, on command of the Warden or designee, the Pharmacist will prepare the necessary syringes for the execution.

2. The Pharmacist shall prepare the syringes as follows, witnessed by the Warden or designee

a. one set of syringes for the lethal injection; (primary syringe)

b. one backup set of syringes for the lethal injection.

3. The syringes containing the drugs shall be prepared and loaded in the following order:

a. one 60-cc syringe, each containing 100 Pancuronium Bromide. (label syringes "2");

b. one 60-cc syringe containing 3.0 grams of sodium 
Pentothal (contents of one gm kits $x$ 3);

c. the Sodium Pentothal, being a Federally controlled drug, shall be prepared last (within two hours of the execution), when it appears that it shall actually be used and as directed by Warden or designee (label syringe "1"); and

d. one extra set of syringes are to be prepared and labeled as "Backup", in the event one of the others is dropped or otherwise needed during the injection and execution procedure.

e. the primary syringes are labeled as Primary 1 and, Primary 2. Backup syringes are labeled as Backup 1, and Backup 2, with number denoting the drug list above.

4 .

a. The drugs outlined in TM 1/05.12, Section E3, may be substituted by another drug based on availability. Pentobarbital with a dosage of $5 \mathrm{gm}$ may be substituted for Sodium Pentothal. Zemuron (Rocuronium Bromide) with a dosage of $1000 \mathrm{mg}$ may be substituted for Pancuronium Bromide (Pavulon). If the drugs specified in E3 or the alternative drugs specified in E4 are both not available then an appropriate drug will be determined and used as a replacement.

b. In all locations where the drugs outlined in TM 1/05.12 E3 are listed in this manual section E4A will be applicable.

F. Injection Procedure

1. The angiocath shall be inserted into the vein of the left arm.

2. The inner needle is then withdrawn and the needle adapter is placed on the angiocath.

3. The flow of normal saline shall be started and administered at a slow rate, TKO (to keep open).

4. Step 1 through 3 shall be repeated for the right arm.

5. The administration sets shall be running at a slow rate of slow, TKO, and ready for insertion of the syringes containing the injection agents.

6. Both set-ups shall be observed to ensure they are both 
functioning properly.

7. No further action is necessary at this time.

G. Lethal Injection Procedure

1. When all preliminaries are completed and when the Warden or designee is ready to proceed with the execution, he shall signal the Executioner.

2. The execution procedures shall then be followed with the Executioner administering a continuous intravenous injection simultaneously.

a. The flow of the normal saline into the arm shall be cut off utilizing the Flo-Trol clamp.

b. The clamp should be moved as close to the "Y" site as possible.

c. The syringe \#1 shall be inserted into the "Y" site and the injection shall commence.

(1) A slow, even flow of the injection shall be maintained with only a minimum amount of force applied to the syringe plunger.

(2) When the entire contents of the syringe have been injected syringe \#1 shall be removed from the "Y" site.

d. The Flo-Trol clamp should then be opened fully and allowed to run for 15 seconds.

e. The Flo-Trol clamps shall then be closed. The Executioner will signal the Warden or designee that the first drug has been administered and flushed.

f. Prior to administration of the \#2 syringe, the Qualified Person will check the condemned's level of consciousness by:

(1) Calling the inmate's name;

(2) Stroking the inmate's eyelids for a response;

(3) Giving the inmate's upper arm or hand a pinch to see if there is a response; and,

(4) Observing the appearance of the inmate being awake (i.e., talking, eyes opening and closing, response to room activity, moving of extremities). 
9. If the Qualified Person determines the condemned has no response, and exhibits no visible signs of being awake, it is assumed the condemned is unconscious. Upon and after the expiration of three minutes from the administration of syringe \#1, the Warden or designee will then give the Executioner a designated sign to proceed with the second (and final) drug. If the condemned does exhibit visible signs of consciousness or being awake the Warden or designee shall instruct the Executioner to administer the backup to syringe \#1, and then proceed in the same manner prescribed under this section for administering syringe \#1.

h. The \#2 syringe shall be inserted into the "Y" site;

(1) The entire contents shall be injected with slow even pressure.

(2) After the \#2 syringe has been given, the Flo-Trol clamp should be opened fully and remain open until the attending qualified official examines the inmate and pronounces death.

i. If at any time one of the lines become blocked and the flow ceases the lethal injection shall be injected into the line which is not blocked.

TM 01/05.13 Pre-Execution Rehearsals and Practices

A. Sufficient rehearsals and practices shall be conducted to carry out an execution in a timely fashion maintaining the necessary security. Practice/rehearsal shall be provided for and may include:

1. briefing;

2. removing the condemned inmate from death-watch/holding cell;

3. strip search, handcuff, leg irons placed on condemned inmate;

4. escort to Execution Chamber;

5. tie-down procedures completed;

6. approximate time for IV injection procedure (execution time-approximate);

7. clearing and escorting witnesses to/from execution site; 
8. condemned inmate's body removed from execution table/chair;

9. condemned inmate's body placed in ambulance;

10. clean-up; and

11. debriefing outlined.

B. Realistic timelines for each function involved in the execution shall be developed working backward from completed execution time.

C. Twelve hours prior to a scheduled execution a final walk-though shall be conducted as directed by the Warden or designee to ensure assigned teams are thoroughly trained, briefed and prepared to carry out the execution.

1. Discrepancies, concerns or proposed modifications due to system problems shall be immediately reported to the Warden or designee.

2. If changes are required, the Warden or designee shall review the proposed changes with the appropriate staff, and if approved, coordinate implementation of the changes with those affected.

TM 01/05.14 Support Services Functions

A. Food Services

1. Death-Watch Meal Service

a. During the final 24 hours, all meals served to the condemned shall be prepared and delivered by staff. No inmate shall have access at any time to the food which is intended for the condemned.

b. The Food Service Director or his designee shall ask the condemned for his choice of a last meal. The inquiry should be made 24 to 48 hours prior to the execution.

c. The final meal may be prepared in the MSP kitchen. The Food Service Director is authorized to make special food purchases locally, to meet the request of the condemned for his last meal, or the meal itself may be purchased locally.

d. The final meal shall be served between 1700 and 2000 hours on the day preceding the execution. 
e. Alcoholic beverages shall not be served nor used for cooking.

2. Coffee and Food Service for Staff

a. Food and liquids will be prepared by Food Service staff for staff directly involved in the execution process.

b. Food and liquid for execution staff shall be prepared by food service staff, not by inmates, to prevent doctoring of food to delay or disrupt the execution.

c. Food and liquid services shall be provided to:

(1) the Warden's Conference Room;

(2) the Media Staging area;

(3) the Special Response Team Commander for delivery to perimeter posts;

(4) the Death Watch Officers; and

(5) the Tie-Down Team.

d. The Food Service Director shall contact the Special Response Team Commander, the Public Information Officer, and the Warden or designee to determine refreshments in each area.

B. Medical Staff

1. Receipt of Death Warrant

Upon receipt of the death warrant a Warden or designee shall:

a. review the medical procedures, post orders and equipment checklist and make recommendations in writing concerning any backup or duplication of any medical paraphernalia that may be necessary to carry out an execution.

2. Twenty-nine to fourteen days

a. Doc staff shall verify with drug vendor availability of drugs and time frame required for delivery.

3. Thirteen to seven days

a. At least thirteen days prior to the execution the Warden 
or designee shall provide to the designated Pharmaceutical Company, authorization to purchase drugs. Authorization shall be in the form of a memorandum including:

(1) the names of the drugs which shall be obtained;

(2) a copy of the judgment of death; and

(3) a copy of the state statute (MCA 46-19-103).

4. Six to Three Days

The Warden or designee shall ensure at least seventy-two hours prior to the execution that a designated staff person complete a check of equipment and materials necessary to carry out the execution.

5. Forty-eight to twenty-four hours

A pre-inventory check shall be made of the equipment.

6. Three hours

a. The Warden or designee shall direct that the drugs be picked up from their storage location by the designated staff person.

b. The drug boxes containing the syringes shall then be surrendered to the Warden or designee.

c. The Warden or designee shall retain the drug boxes until turned over to the contract pharmacist for the purpose of preparation of the syringes.

d. At the direction of the Warden or designee, two hours prior to the execution, the pharmacist shall begin to prepare the syringes with the Warden or designee observing the process.

e. The pharmacist shall maintain personal custody of the syringes until such time as they are surrendered to the Warden or designee.

7. Two Hours

a. During the final two hours:

(1) all syringes shall be prepared by the contract pharmacist at the direction of the Warden or 
designee when it appears the execution shall be carried out;

(2) a medical-response team shall be on standby to provide any medical attention which may be needed during the time of the scheduled execution;

(3) a final pre-inventory check of the equipment shall be completed;

(4) a Montana State Prison emergency equipment kit and a backup kit shall be made available at the execution site; and

b. Equipment and lethal drugs shall be gathered up by the Setup Officer/designee following the execution.

(1) The Setup Officer/designee shall be responsible for disposal of the medical equipment used for lethal injection

(2) The unused drugs shall be secured in the Investigator's secure vault for a minimum of 10 days following the execution.

(3) At least 10 days after the execution and at the direction of the Warden or designee, a designated MSP staff member and DOC Investigator shall dispose of the drugs used for lethal injection in accordance with state and federal laws.

\section{Maintenance Staff}

1. Receipt of Death Warrant

a. Upon receipt of the death warrant the Warden or designee shall:

(1) review the maintenance procedures and the equipment checklist and make recommendations in writing for changes, additional equipment, etc., and provide such recommendations to the Warden or designee 50 days prior to the scheduled execution date;

(2) confer with the Maintenance Services Manager and assign all execution related tasks to be completed. 
b. The Maintenance Services Manager shall prepare a task completion calendar 45 days preceding the execution date and shall forward it to the Warden or designee for approval, including but not limited to:

(1) a review of the maintenance procedure and equipment checklist of the Execution Chamber.

(2) recommendations to the Warden or designee in writing of changes, additional equipment, etc., 29 days prior to the scheduled execution date.

(3) identification of strategies to ensure that all systems, equipment, and mechanisms associated with the execution facilities are functional and are readily repairable given an unexpected malfunction.

(4) identification of emergency equipment, materials, and substances necessary to ensure that system, equipment, and/or mechanism malfunction are expeditiously remedied.

(5) establishment of inspection checklist and time frames for:

a. the facility designed for the execution;

b. the death-watch and holding cells; and

c. emergency backup systems.

(6) ensuring that all maintenance service/repair vehicles are in good operational condition and supplied with equipment, tools, and supplies necessary to correct all execution related emergencies.

(7) identification of maintenance personnel necessary to address all execution day emergencies.

\section{Twenty-nine to Fourteen Days}

The Maintenance Services Manager shall:

a. Complete a pre-inventory check of the necessary equipment;

b. Complete a written report to the Warden or designee of equipment, etc. requiring repair, replacement or duplication, including recommendations to correct problems 
and the time-frame necessary to make the corrections.

3. Thirteen to seven days

The Maintenance Services Manager shall:

a. Verify that the Execution Chamber is in a state of readiness for the execution.

b. Install the bunk and necessary equipment in the death-watch area.

c. Conduct an inspection of the following:

1. execution trailer;

2. death-watch and holding cell; and

3. emergency backup systems and equipment.

4. Seven to Three Days

a. An inspection shall be completed:

1. at the execution trailer;

2. death-watch and holding cells;

3. emergency backup systems and equipment.

b. A pre-inventory check shall be completed to ensure that all equipment is functional and in place.

5. Three days to Final 24 hours

a. All procedures and duties in section four shall be completed and noted.

b. The Maintenance Services Manager shall ensure that the response team will be in place, as required, for exigent circumstances that may arise. The response team shall include:

6. 72 to 24 Hours Before Execution

a. Person available for emergency maintenance problems which might occur in the security areas.

b. A three-man team available by telephone for any maintenance problems which might occur within the institution and for emergency services needed. 
7. 24 Hours Before to Eight Hours After the Execution

a. A three-man maintenance team available for emergency maintenance and services problems which might occur within the institution.

b. A three-man fire team available to support the institution in case of emergency.

c. One person available in a supervisory capacity for dispatching of the maintenance and fire emergency teams.

TM 01/05.15 Execution Site

A. Execution Site will be a location designated within the Locked Housing Unit-I Compound that includes the Execution Chamber.

B. Execution Chamber will be comprised of four areas arranged to cover the execution functions involved:

1. Executioner-enclosed area for the Executioner and drugs used for the execution with a separate entrance from the execution chamber sufficient to protect identity of Executioner.

2. Condemned-open area for placement of the gurney where the condemned inmate will be placed for execution which is immediately adjacent to the Executioner area. Area will include space for Warden, assigned Associate Warden or other designated staff/contract persons to observe condemned and execution process.

3. Witnesses-open area for witnesses to observe the execution with a barrier between condemned and witnesses. Area will include sufficient space for twelve execution witnesses, and two correctional officers (observing and maintaining security of witnesses). Witnesses will be segregated by type of witness and all will have a clear view of the execution area.

4. DOC/MSP Staff-area for monitoring phones with Governor and Attorney General's Office. Open area for four staff members/contract persons to assist with execution as needed and monitor phone lines. 
C. Execution chamber will be designed in a manner to separate the four areas identified in B1-4 in an efficient manner with the requirement that the Executioner area be completely separate and restricted in access from the other areas.

D. Warden or designee will determine the layout of the execution chamber. 
TM $01 / 06.00$

TM $01 / 06.01$

TM $01 / 06.02$

TM $01 / 06.03$

TM $01 / 06.04$
STAYS, COMMUTATIONS AND OTHER DELAYS

General Provisions

Non-Judicial Interruption of Execution

Communication of Stays, Commutations or Delays

Procedures to Implement Last-minute Stays 
TM $01 / 06.00$

STAYS, COMMUTATIONS AND OTHER DELAYS

TM 01/06.01 General Provisions

A. Purpose of Chapter

The purpose of this chapter is to:

1. cite the authority of entities capable of causing execution:
a. stays;
b. commutations; and
c. other delays;

2. specify the manner of communicating such delays/commutations; and

3. provide the procedures for implementing the delay/commutation.

B. Policy

It is the policy of Montana State Prison that:

1. procedures shall be in place to receive and ensure proper handling of legal interruptions of the execution countdown;

2. staff understand their roles and the prison's responsibilities in the event of such interruptions; and

3. contingency plans provide options to deal with:
a. temporary delays;
b. lengthy delays; and
c. commutations.

TM 01/06.02 Official Interruption of Execution

A. Executive clemency: kindness, mercy or leniency which may be exercised by the Governor toward a convicted person, in the form of remission of fines or forfeitures; the commutation of a sentence to one that is less severe, respite or pardon. 46-23-301 MCA

1. All judicial remedies need not be exhausted before filing an 
application for clemency, but the automatic review before the Montana Supreme Court may not be pending at the time of the application. The Board of Pardons and Parole may consider cases of executive clemency only upon application to the Board, which must be made no later than ten days after the district court sets a date of execution.

2. Authority to file for clemency: The application may be filed only by the person who committed the crime, the person's attorney acting on the person's behalf and with the person's consent, or by a court-appointed next friend, guardian or conservator acting on the convicted person's behalf.

3. The Board is to investigate and make a recommendation within 30 days of hearing, based on:

1. all circumstances surrounding the crime for which the applicant is convicted; and

2. the individual circumstances related to social conditions of the applicant prior to commission of the crime, at the time the offense was committed, and at the time of the application for clemency.

If the Board recommends clemency, a copy of the decision, together will all papers used in the case, shall be immediately transmitted to the governor.

4. The Board shall advise the Governor and may recommend that clemency by granted or denied. In capital cases, the Board shall transmit its recommendation. While the Governor is not bound by any recommendation of the Board, he shall review the record of the Board's hearing and the Board's recommendation before granting or denying clemency. The Governor has the final authority concerning clemency, and there is no appeal from his decision.

B. Respite: Respite is a type of clemency which only the Governor has the authority to grant, and only when an application of executive clemency is pending before the Board of Pardons and Paroles. Respite may be granted prior to any review or recommendation by the Board.

1. A respite is temporary in duration, and must be for a specific time.

2. When a respite is granted, it has the effect of staying execution of the death warrant. Where clemency is not otherwise granted, the death warrant is again in effect at 
the expiration of the period of respite and the execution must take place on the date of expiration of the respite. 46-23-315 MCA

\section{JUDICIAL INTERRUPTIONS OF EXECUTIONS}

1. Pregnancy: If execution proceedings have been stayed because it has been determined pursuant to sections 46-19-203 and 204, MCA, that the woman against whom judgment of death is rendered is pregnant, the inquisition is to be transmitted to the Governor. When a governor is satisfied that the woman is no longer pregnant, he may issue his warrant appointing a day for the execution of the judgment.

2. Mental Fitness: A court may stay the execution proceedings if it finds that defendant lacks mental fitness. 46-19-201, 202, MCA. Mental fitness is determined pursuant to the provisions of Title 46, chapter 14, MCA. If a court finds the defendant lacks mental fitness, the execution of judgment may be suspended by the court and the court shall commit him to the custody of the Superintendent of Montana state Hospital to be placed in an appropriate institution of the Department of Institutions for so long as the lack of fitness endures.

3 Mental Fitness Restored: The court on its own motion, or upon application of the Superintendent of Montana State Hospital, the county prosecuting officer, or the defendant or his legal representative, may determine after hearing, if a hearing is requested, that the defendant has regained fitness to proceed. The court must order the Warden or designee to carry out the execution. If, however, the court is of the view that so much time has elapsed since the commitment of the defendant that it would be unjust to proceed with execution of the sentence, the court may suspend the execution of the sentence and may order the defendant to be discharged. 46-19-202(3), MCA.

4. Jurisdiction over Mental Fitness Question: It is not clear which court or courts may have jurisdiction to determine a defendant's mental fitness for execution. It logically should be: (1) a district court or judge thereof of the county in which the person sentenced to death is restrained of his liberty; or (2) the district court or a judge thereof in the county in which the conviction and sentencing occurred (preferably the sentencing judge). The statutes do not clearly specify which courts have jurisdiction of such an action, however. 
5. General Stay Power: Under the statutes setting forth the general powers of courts, it is clear that a court has the means to carry its jurisdiction into effect. See 3-1-111,113, MCA. The courts which may have jurisdiction of matters which would allow them to issue a stay may include:

a. State Courts

1. Trial Courts

a. County in which defendant is being held.

1. State habeas corpus 46-20-202, MCA

b. County in which defendant was convicted or sentenced.

1. State post-conviction relief petition. 46-21-103, MCA.

2. District court appeal. 46-20-204, MCA.

2. Montana Supreme Court or justice thereof.

a. State habeas corpus action. 46-20-202, MCA.

b. State post-conviction relief. 46-21-103, MCA.

b. Federal Courts - 28 U.S.C. 2254; federal habeas corpus.

1. Federal district court for the district of Montana (any one of the Montana federal judges);

2. Ninth Circuit Court of Appeals or one of its justices;

3. United State Supreme Court or one of its justices.

D. Board of Pardons and Parole: The Board has the authority to investigate and report to the Governor with respect to all cases of executive clemency. 46-23-301, MCA. The Board itself may not grant executive clemency but may advise the Governor and recommend action to be taken. A majority of the Board must advise, investigate, and approve each case before the action of the Governor shall be final. It has no power on its own to issue a stay. 
E. Warden or designee

1. Pregnancy: If there is a good reason to suppose a woman against whom a judgment of death is rendered is pregnant, the sheriff of the county, with concurrence of the judge of the court by which the judgment was rendered, must summon a jury of three physicians to inquire into the supposed pregnancy. Immediate notice of the inquiry must be given to the county attorney of his own county who must attend the inquiry and may produce his own witnesses. If it is found by the inquiry that the woman is not pregnant, the Warden or designee of the Montana state Prison shall execute the judgment. If it is found that the woman is pregnant, the Warden or designee shall suspend the execution of judgment and transmit the inquisition of the Governor. 46-19-203, 204, MCA.

TM 01/06.03 Communication of Stays, Commutations or Delays

A. $\quad$ Practical Attempts to Interrupt Execution

1. Any phone call to the prison preceding the execution which attempts to stay the execution by court order should be rerouted through the established phone and FAX networks set up between the Attorney General's Office, the Governor's Office, and the prison. Any call from a court should be sent directly to the Attorney General's Office administrative phone line so that the Attorney General's office may verify the validity of the call by determining whether the call is being initiated by a court which has jurisdiction to intercede. Validation will entail exchange of the code words selected for the case, telephoning the court back for verification, and transmission of a hard copy of the stay order through the FAX network to the Attorney General's Office. The Attorney General will then personally transmit any stay by telephone over the hot line, with notice to the Governor via the administrative phone network, and will also transmit hard copies of the stay to the Governor and the prison over the FAX network

2. Any respite from the Governor should be personally transmitted by the Governor over the hotline to the prison, with notice to the Attorney General via the administrative phone network, and by written respite transmitted to the Attorney General's office and to the prison over the FAX network. 
B. Prior to the Final Execution Countdown

If Montana State Prison receives an order from a competent court or the Governor ordering a respite, reprieve, stay, commutation, pardon or other action which requires the suspension or termination of the execution:

1. the Attorney General's Office shall be contacted for direction; and

2. a decision made by the Warden or designee concerning the status of planning and preparation for the execution.

C. $\quad$ Postponement

1. A dedicated communication line shall be established between the place of execution and the Governor's office. A second dedicated communication line shall be established between the place of execution and the Attorney General's office. The dedicated lines shall remain operable until the defendant is pronounced dead or until a postponement is granted by one of the following:

a. A stay granted by a court of competent jurisdiction, which must be communicated directly to the Warden or designee by the Attorney General's office.

b. A respite granted by the Governor under section 46-23-315 MCA, which shall be communicated directly to the Warden or designee by the Governor, or the Governor's Counsel.

D. Final Clearance for Execution

The Warden or designee shall verify clearance to continue with the execution using the administrative priority line.

TM 01/06.04 Procedures to Implement Last-minute Stays

A. Upon receiving a stay during the final countdown, the first effort shall be to determine the probable length of the delay.

B. If the witnesses have not been moved from the staging area, they shall be held at that location until further instructions are received to proceed with or terminate the execution.

C. If the inmate has not been moved from the holding cell, they shall be held at that location until further instructions are received 
to proceed with or terminate the execution.

D. If witnesses are already at the Execution Chamber and the inmate tied down, the witnesses shall be moved back to the staging area and the inmate returned to the holding cell.

E. if the execution is indefinitely stayed, set for re-sentencing, commuted, or halted by pardon, the execution shall be halted. Witnesses and condemned will be notified. 
TM $01 / 07.00$

TM $01 / 07.01$

TM $01 / 07.02$

TM $01 / 07.03$

TM $01 / 07.04$
WITNESSES

General Provisions

Designation of Persons Required, Permitted or Prohibited from Witnessing

Categories of Witnesses

Others Who May Attend 
TM 01/07.00 WITNESSES

TM 01/07.01 General Provisions

A. Purpose of Chapter

The purpose of this chapter is to:

1. identify the types and numbers of witnesses permitted to attend the execution, and

2. to provide legal requirements concerning the witnessing of the execution.

B. Policy (MSP Procedure 3.6.11)

It is the policy of Montana State Prison that:

1. procedures for selecting witnesses to the execution shall conform with state law and Department of Correction's policy; and

2. witnesses shall agree to security measures set out by the prison including a background check and shall be subject to search prior to being admitted.

TM 01/07.02 Designation of Persons Required, Permitted or Prohibited from Witnessing the Execution

1. Department of Corrections policy (3.6.1) generally sets out who may attend and witness the execution.

a. At least 12 persons must observe the execution, three of whom may be designated by the defendant.

2. The Prison Chaplain and/or a clergyman selected by the defendant shall be available prior to, during, and after the execution.

3. No one under the age of 18 will be allowed to observe the execution

4. No inmate will be allowed to observe the execution.

TM 01/07.03 Categories of Witnesses

Following are the types of witnesses and the requirements for each, as set out by Department of Corrections policy (DOC 3.6.1, MSP 3.6.1, and 46-19-103 6b MCA) 
A. Condemned Inmate's Witnesses

1. The condemned inmate may select three people to witness the execution.

2. The inmate must give the names of the witnesses he selects to the Warden or designee 14 days prior to the execution date.

B. News Media Witnesses

1. Three members of the news media shall be permitted to witness the execution and may be included as part of the required 12 .

2. Selection shall be at the discretion of the Warden or designee.

3. Refer to TM 01/08 for selection procedures.

C. Victim's Witnesses

1. Three persons designated by the family of the victim of the crime.

D. State Witnesses shall be permitted to witness the execution and may be included as part of the required 12 .

1. The Director will select witnesses to be part of the 12 required witnesses.

2. The state witnesses may include, but will not be limited to, sentencing judge, prosecuting attorney, the sheriff from the county where the crime was committed, and additional victim's witnesses.

State witnesses may exceed three if the other designated witnesses in media, condemned and victim are not filled as designated in $\mathrm{A}, \mathrm{B} \& \mathrm{C}$ above.

TM 01/07.04 Others Who May Attend

A. The following persons may also attend the execution:

1. Staff as determined necessary for the execution by the Warden or his designee.

a. The "necessary staff" shall include those persons identified in the post orders and procedures in TM 01. 
b. "Necessary staff" shall not be limited to members of Montana State Prison, but shall include members of allied agencies assisting with the execution.

2. no more than three correctional officials from other states that are preparing for executions may be allowed to attend, but no more than two correctional officials may be from any one state.

B. For those persons who shall carry out the execution or serve in support roles in the execution area, refer to TM 01/05. 
TM 01/08.00 NEWS MEDIA PROCEDURES

TM 01/08.01 General Provisions

TM 01/08.02 News Media Selection

TM 01/08.03 Alternate Coverage/Accommodations

TM 01/08.04 News Media Attendance at the Execution

TM 01/08.05 Limitations on Coverage

TM 01/08.06 News Media Briefing

TM 01/08.07 News Media Support and Equipment 
TM 01/08.00 NEWS MEDIA PROCEDURES

TM 01/08.01 General Provisions

A. Purpose of Chapter

The purpose of this chapter is:

1. to provide the policies, procedures and requirements for news media access to the execution and to information relating to the execution.

2. to provide the procedure for:
a. releasing background information;
b. releasing information during the execution;
c. coverage of the execution; and

3. to provide requirements for safeguarding the institution and protected information.

B. Policy

1. It shall be the policy of Montana State Prison to permit news media access to the execution and information concerning the execution consistent with the requirements of the laws and constitutions of the United States and the state of Montana.

2. The prison is generally required to provide no more news media access to the inmates and the facilities it supervises and controls than that available to the general public.

3. The Department of Corrections policy recognizes the need for the public to be informed concerning executions conducted by Montana State Prison. The Warden or designee will determine content and timing of all information to be released.

a. The prison will participate and cooperate with the news media to inform the public concerning the execution.

b. Information shall be provided in a timely manner.

4. If the condemned is willing, the Warden or designee may allow a brief opportunity for him to speak with the news media. If allowed, the interview will be held no later than 48 hours prior to the scheduled date of the execution at a time and location determined by the Warden or designee. Interviews 
will not be permitted during the final 48 hours.

5. Access to the interior of the execution chamber by media will be limited to media day only. The three witnesses to the execution will be allowed access during the execution, along with the other witnesses under escort.

6. Photographic and film coverage of the exterior of the Execution Chamber and prison compound may be allowed by the Warden or designee prior to the scheduled execution on the day specified as media day. No photographic or film coverage will be allowed after that time.

7. During exigent circumstances, communication may be temporarily suspended until the situation has been stabilized. Exigent circumstances shall include, but not be limited to:
a. riots;
b. hostage situations;
c. fires or other disasters; or
d. other inmate disorders.

TM 01/08.02 News Media Selection

A. Number in Attendance

The Department shall permit three members of the news media to witness the execution.

B. Authority to Select

The Warden or designee shall be responsible for the method of selection of the news media who will be permitted to witness the execution. MSP will determine process and send information out to the media.

\section{Selection Process}

1. After the court sets a date for the execution, the news media members may request permission to witness the execution by directing such request, in writing, to the attention of the Warden or designee.

a. Requests should be received 21 days prior to the 
execution

b. If an expedited execution date or other circumstances create a hardship on the news media generally, the request deadline may be extended. Such extensions shall be announced by the Warden or designee.

c. News media witnesses will be limited to three- -two from the Montana media and one from a national/international news organization.

d. Only the first 40 requests received will be considered.

2. Requests for consideration may be granted by the Warden or designee and are subject to the limitations set forth in this section. Media that MSP has experienced problems with in the past will not be allowed. Requests should contain the following:

a. a statement setting forth facts showing that the requesting individual falls within the definition of "member of the news media" as defined in these regulations;

b. an agreement to act as a pool representative as described in these regulations;

c. an agreement that the media member will abide by all prison conditions, rules and regulations while in attendance at the execution;

d. agreement that the media member will conduct him/herself consistent with existing press standards;

e. agreement that the media member will attend the media day activities. Failure to attend Media Day by media witnesses or alternates will forfeit the media member's' chance to be a witness.

3. At the conclusion of the lottery process all verified applicants and alternates will be notified of the outcome.

4. Following the application deadline, the Public Information officer will conduct lotteries in the following categories:

1) Montana Broadcasters

2) Montana Press Reporters

3) National/International Reporters. 
The final Montana News Media witness position shall be awarded to a Montana Associated Press reporter selected by their agency.

Alternate media witnesses shall be drawn by a lottery for each category of media witnesses. Alternate media witnesses must attend media day activities to be eligible as an alternate media witness.

If there are no applicants for a given category, then all unselected applicants will be placed in a container and the vacant witness slots drawn for.

At the conclusion of the lottery process all verified applicants will be notified of the outcome.

TM $01 / 08.03$

Alternate Coverage/Accommodations

A. Additional Media Selected

1. Other media who request and receive permission shall be permitted on prison property during the execution and staged at the DoC Training Center (Old National Guard Armory).

2. The additional media selected:

a. shall not exceed 36 in number.

B. News Media Staging Area

1. The location for the additional media selected to be on site during the execution will be a briefing area at the Ranch 1 Training Center. The media selected to witness the execution will wait at the staging area until transported to the execution chamber.

2. MSP will specify in the news media information packets which will be provided for media resources at the briefing area.

3. Media members must contact the Public Information Officer at least 14 days prior to the execution date to make any special arrangements for special hookups, etc. Any expense incurred shall be borne by the specific news media organization requiring the special equipment.

4. The media staging area shall be made available to selected members of the news media at 1700 hours the day prior to the scheduled execution date. Satellite and up-link trucks may, 
on a case by case basis, request earlier set-up beginning as early as 1430 hours.

5. No special access or briefings will be provided to members of the news media who are not selected as witnesses or selected for the alternate site.

C. Briefing Media at the Media Staging site

1. The Public Information Officer shall arrange for:

a. pre-execution briefings;

b. distribution of media briefing packages;

c. briefings throughout the execution event; and

d. post-execution briefings by the news media who witnessed the execution.

2. The news media members witnessing the execution shall be returned to the media staging area to answer questions from media members.

TM 01/08.04 News Media Attendance at the Execution

A. The Warden or designee shall permit the three members of the news media selected in accordance with these regulations to witness the execution.

B. Each media member attending the execution shall be carefully searched prior to admittance to the Execution Chamber.

1. If a media member is suspected of concealing or found to have in their possession contraband which includes but is not limited to weapons, drugs, alcohol, tobacco, cell phone, camera or any other items disallowed by policy, they will not be allowed access to prison grounds. Prison grounds include all areas of the prison and prison ranch including designated checkpoints. Strip searches of media will not be conducted.

a. Electronic or mechanical recording devices are not allowed in the execution chamber and include, but are not limited to, still, moving picture or videotape cameras, tape recorders or similar devices, broadcasting devices, or artistic paraphernalia, such as notebooks, and drawing pencils or pens, etc. 
b. Only a small notebook (no larger than 6" x 9") and two pens or pencils shall be permitted.

2. The PIO shall conduct a pre-execution briefing with the three selected members of the news media at the media staging area.

a. After the short briefing by the Public Information Officer, but prior to being searched, each member of the press will be allowed to go to the bathroom or gather any needed authorized materials.

b. Each media witness shall be led one at a time into a private room where he will be searched by an officer of the same sex. Women shall be searched in a room separate from the men.

c. After being searched, members of the news media shall be escorted directly to the Execution Chamber. Media members shall not be allowed to physically make contact with any other person after they are searched.

C. The Warden or designee shall not exclude any media member duly selected in accordance with these regulations from attendance at the execution except as described, nor may the Warden or designee cause a selected media member to be removed from the Execution Chamber unless the media member:

1. refuses to submit to a reasonable search as permitted in these regulations;

2. faints, becomes ill or requests to be allowed to leave during the execution;

3. causes a disturbance within the Execution Chamber that disrupts the conduct of the execution; or

4. refuses or fails to abide by the conditions and regulations set forth by the prison, specifically MSP policies 5.4.4 Inmate Visiting and 3.1.18 Searching and Detaining Non-offenders.

D. The Execution Chamber shall be arranged so as to provide space for the attending media members and the space arranged shall have a view of the execution site, with the exception of those directly administering the method of execution.

E. The selected media members shall be transported as a group to the execution location prior to the execution and shall be allowed to remain there throughout the proceeding. 
F. The prison shall designate a representative or representatives, preferably the Public Information officer, to remain with the media members throughout the execution proceedings.

G. Media members shall be admitted to the execution media staging area on the date set for the execution only after:

1. proof of identification has been presented to the perimeter checkpoint. Photo ID is required and will be exchanged for a visitor pass;

2. being issued special identification credentials;

3. receiving an orientation by the Public Information Officer; and

4. signing an agreement to abide by the conditions required of media witnesses to the execution.

H. News media representatives shall, after being returned from the execution to the staging area, act as pool representatives for other media representatives covering the event.

1. The pool representatives shall meet at the designated staging area and provide an account of the execution. They shall freely answer all questions put to them by other media members and shall not be permitted to report their coverage of the execution back to their respective news organizations until after the non-attending media members have had the benefit of the pool representatives' account of the execution.

a. News media members attending the post-execution briefing shall agree to remain in the briefing room and not leave or communicate with persons outside the briefing room until the briefing is over.

b. The briefing shall end when the attending news media members are through asking questions or after 60 minutes, whichever comes first.

2. The media witnesses shall be transported as a group between the staging area and the Execution Chamber in prison transportation. Media members arriving late shall not be permitted to attend the execution.

TM 01/08.05 Limitations on Coverage

A. The prison may alter these regulations to impose additional 
conditions, restrictions and limitations on media coverage of the execution when such requirements become necessary for the preservation of prison security, personal safety or other legitimate interests which may be in jeopardy.

B. Should such extraordinary circumstances develop, the additional conditions and restrictions shall be no more restrictive than required to meet the exigent circumstances.

TM 01/08.06 News Media Briefing

A. $\quad$ Pre-Execution Briefing Packets

1. The Public Information Officer shall prepare a press briefing packet for reporters approved to witness the execution and those in the news media staging area.

2. The briefing press packet should be provided to news media representatives as they arrive at the press staging area.

3. The contents of the press briefing packet shall include, but not be limited to, biographical information on the condemned, the list of official witnesses, execution procedures, sequence of events, and the history of executions in Montana.

4. Updates will generally be communicated and/or distributed to the press on an hourly basis beginning about 1700 hours the day preceding the execution. Briefing updates should include:
a. a summary of activities related to the execution procedures and sequence of events; and
b. a summary of the condemned inmate's activities during his final 24 hours.

B. Post-Execution Conference

1. The Public Information Officer shall read a prepared statement to the press, prior to the post-execution press conference, announcing that the execution has been completed. The announcement shall include but not be limited to:
A. Time of execution;
B. Time the condemned was pronounced dead; and 
C. The condemned's final words.

2. The Public Information Officer shall introduce the three members of the press who witnessed the execution and facilitate the post-execution conference.

3. The post-execution conference shall begin immediately following the arrival of a designated MSP staff member and the three pool reporters from the execution site.

4. The Warden or designees may appear and answer questions at the press conference.

5. The post-execution conference shall continue for 60 minutes or until the questioning of the reporters who witnessed the execution has been completed, whichever comes first.

\section{Travel Routes}

1. The Public Information Officer shall coordinate all the traffic routes to and from the media staging area with the Special Response Team Commander.

2. The Public Information Officer shall provide the Special Response Team Commander with a list of news media personnel invited to the media staging area.

TM 01/08.07 News Media Support and Equipment

A. Electrical Outlets

Each news agency must communicate its needs for electrical power to the Public Information Officer 14 days prior to the scheduled execution.

B. Refreshments

1. The Public Information Officer will order light refreshments through the Food Service Manager for the press, one week prior to the scheduled execution.

2. Refreshments will be served to the media at the staging area.

C. News Media Support Vehicles

1. The Public Information Officer shall coordinate transportation needs for the pool reporters invited to 
witness the execution with the Security Major. 
TM 01/09.00 COMMUNICATIONS: INFORMATION PROCEDURES

TM 01/09.01 General Provisions

TM 01/09.02 Operations

TM 01/09.03 Screening/Routing Incoming Calls

TM 01/09.04 Documenting Calls

TM 01/09.05 Other Duties 
TM 01/09.00 INFORMATION PROCEDURES

TM 01/09.01 General Provisions

A. Purpose of Chapter

The purpose of this chapter is to:

1. provide the guidelines for handling public telephone inquiries, complaints and other communications during the execution;

2. identify staffing requirements and operating procedures; and

3. determine operational authority and responsibility.

B. $\underline{\text { Policy }}$

It is the policy of Montana State Prison that:

1. all communication concerning the execution, including but not limited to public/news media telephone inquiries, complaints and security threats, be handled in an efficient manner;

2. inquiries and other communication relating to the execution be routed to either the Warden or designee or the Public Information officer;

3. during the execution period, staff shall be assigned as needed to deal with both incoming calls and briefing news media at the staging area. Staff assigned include the Public Information Officer, and/or Administrative Assistants to the Warden or designees;

4. communication be processed in such a manner that it allows the prison switchboard to handle normal and routine business, while routing calls relating to the execution to staff specifically designed to handle the variety of problems associated with execution-related calls; and

5. whenever possible, execution-related calls be documented for future reference and evaluation.

TM 01/09.02 Operations

A. An information center shall commence operation at 1700 hours on the day preceding the execution and shall remain in operation until 
approximately one hour after the execution.

B. The Public Information officer shall arrange and coordinate coverage of telephones based on the volume of calls and the need to handle other related duties.

C. One staff member will be assigned to remain with the news media at the staging area beginning at 1700 hours on the day preceding the execution. This person will act as liaison with the Public Information officer and will not answer questions from those assembled. Briefings will be provided to the news media on an hourly basis (see TM 01/08.06).

TM 01/09.03 Screening/Routing Incoming Calls

A. Business, Personal and Inquiry Calls

1. All business calls should be screened and routed to the appropriate office.

2. All inquiry calls should be routed to either the Warden or designee's Office or the Public Information officer.

3. All personal calls should be screened and routed to the appropriate office.

B. Crank and Emergency Calls

1. Crank and emergency calls received at Montana State Prison shall be transferred immediately to the Warden or designees.

2. If bomb threats or other threats of violence are received, the person receiving the call shall immediately notify the Command Post.

TM 01/09.04 Documenting Calls

Whenever possible, all calls except personal calls shall be documented.

TM 01/09.05 Other Duties

A. Notification of Victim/Victims' Families

The Warden or designee's Office and/or Public Information Officer shall: 
1. provide information on request to the victim/victims' families.

2. notify by telephone those victims/victims' families who request notification immediately after the execution has been carried out; and

3. notify law enforcement agencies providing security to victims/victims' families that the execution has been carried out, if requested. 
TM 01/10.00 COMMUNICATIONS: ELECTRONIC SUPPORT

TM 01/10.01 General Provisions

TM 01/10.02 Communication Requirements

TM 01/10.03 Communication Frequencies/Radio Call Signs

TM 01/10.04 Execution Telephones 
$\operatorname{TM} 01 / 10.00$

COMMUNICATIONS: ELECTRONIC SUPPORT

TM 01/10.01 General Provisions

A. Purpose of Chapter

The purpose of this chapter is to:

1. provide the electronic communications policies and procedures during the execution event for:

a. prison personnel; and

b. allied agency personnel; and

2. give call signs, pager numbers and other important information.

B. $\underline{\text { Policy }}$

It is the policy of Montana State Prison that:

1. telephones shall be the primary means of direct communication between agencies, facilities and personnel in carrying out a final order of execution;

2. direct telephone communication shall be installed between the Warden or designee's office, the execution site, the Attorney General's office and the Governor's office and home.

3. redundancy of communication lines shall be sufficient between critical locations to ensure that communication capability is not interrupted.

TM 01/10.02 Communication Requirements

A. Telephone Communication

1. Telephones shall be the primary means of direct communication between agencies, facilities and personnel in carrying out a final order of execution.

2. The primary telephone line between the execution site, the Attorney General's office, and the Governor's office and home, shall be a dial-less, auto-ring telephone. When any handset is lifted the telephone at the other end automatically rings. 
a. The secondary or backup telephone line between the execution site, the Attorney General's office, and the Governor's office and home shall be a dedicated private line with priority status.

b. A prison PBX extension number shall be available as a backup to the secondary line.

3. Thirty days prior to the scheduled execution, the Warden or designee will formally contact the Department of

Administration to implement installation and testing of the execution telephones.

4. In the event of total telephone failure the Warden or designee shall be able to receive radio communication directly using a portable hand-held radio unit.

\section{B. Radio Communication}

1. Radio communication shall be used to coordinate security, conduct normal operations within facilities and provide emergency backup communication. The frequencies and their uses are listed in TM 01/10.03.

2. Because of the large number of personnel involved in the execution operation, and the different channels which must be coordinated, unnecessary radio traffic should be avoided.

TM 01/10.03 Communication Radio Call Signs

During the course of the actual execution process, MSP will have designated security teams established for assigned responsibilities. Due to the variety of responsibilities, a designated radio channel plan will be developed to ensure normal prison operations and execution operations can be carried out with a minimal amount of interference or disruption.

A. Operations/Execution/Call Signs

$\begin{array}{lr}\text { Security Patrol - } 1 \text { North } & \text { SP-1 } \\ \text { Security Patrol - } 2 \text { South } & \text { SP-2 } \\ \text { Check Point 1 - Airport Hill } & \mathrm{CP}-1 \\ \text { Check Point 2 Check Point Building } & \mathrm{CP}-2 \\ \text { Death Watch Officers } & \mathrm{W}-1 \\ \text { Tie Down Officers } & \mathrm{TD}-1 \\ \text { Escort Officer - State } & \mathrm{E}-1 \\ \text { Escort Officer - Victim } & \mathrm{E}-2 \\ \text { Escort Officer - Media } & \mathrm{E}-3\end{array}$


TM 01/10.04 Execution Telephones

Telephones in the Execution Chamber include:

1. an automatic ring-down telephone connection with the Attorney General's office, and the Governor's office and home.

2. a private, priority line for incoming and outgoing calls.

3. A separate phone jack for the holding cell in Locked Housing Unit-I shall be located in the hallway so a direct line will be available to the holding cell.

4. A dedicated line between the execution chamber and the Warden or designee will be installed. 
TM 01/11.00 SECURITY ZONES

TM 01/11.01 General Provisions

TM 01/11.02 Description and Control of Security Zones

TM 01/11.03 Enforcement

TM 01/11.04 Duration of Security Zones

TM 01/11.05 Escort Through Security Zones 
TM 01/11.01 General Provisions

A. $\quad$ Purpose of Chapter

The purpose of this chapter is:

1. to identify and define the security zones which shall be established and maintained during the execution operation;

2. to establish security requirements for each security zone;

3. to define operational measures related to securing each zone; and

4. to identify restrictions on public access to Montana state Prison property during the execution operation.

B. $\quad \underline{\text { Policy }}$

It is the policy of the Department that:

1. during the execution operation, MSP property and certain other areas be divided into four security zones (see TM 01/11.02), including:
a. inner-perimeter zone;
b. controlled-perimeter zone;
c. restricted zone; and
d. extended zone;

2. access to the inner-perimeter, controlled, and restricted security zones shall be permitted only for persons whose names are on the Master Security Pass List and who have the proper security pass or prison ID;

3. A request will be made by the Department of Corrections to restrict air space over Montana state Prison property.

4. persons engaged in unauthorized entry onto Montana State Prison property may be prosecuted;

5. persons attempting to breach the inner-security zone shall not only be prosecuted, but if the threat to prison security and/or public safety is great enough, may risk exposure to use of force to prevent the defeat of inner perimeter security; and 
6. controlled areas west of the Golf Course Hill shall be accessible to the general public to the extent specifically authorized by the prison.

TM 01/11.02 Description and Control of Security Zones

A. Inner-Perimeter Zone

1. The inner-perimeter zone includes:

a. the Maximum Security building and yard and No Man's Land; and

b. the execution site.

2. This zone shall be controlled to prevent:

a. escape by or outside rescue of the condemned or other inmates;

b. disruption or interruption of the execution by outside forces;

c. unauthorized entry into the most secure areas of Montana State Prison; and

d. introduction of:

(1) weapons;

(2) implements of escape; or

(3) other contraband.

3. To prevent escape by inmates, deadly force may be employed consistent with the requirements of MSP policy.

4. Persons attempting to breach the inner-security zone shall not only be prosecuted, but if the threat to prison security and/or public safety is great enough, may risk exposure to use of force to prevent the defeat of inner perimeter security.

B. Controlled Perimeter Zone

1. The controlled zone includes all prison property inside the double and single-fenced compounds. Trespass or unauthorized entry into the controlled zone may be 
prosecuted.

2. This zone shall be controlled to prevent:

a. escape by or outside rescue of the condemned or other inmates;

b. disruption or interruption of the execution by outside forces;

c. unauthorized entry into the most secure areas of Montana state Prison; and

d. introduction of:

(1) weapons;

(2) implements of escape; or

(3) other contraband.

3. To prevent escape by inmates, deadly force may be employed consistent with the requirements of MSP policy.

4. Persons attempting to breach the controlled perimeter zone shall not only be prosecuted, but if the threat to prison security and/or public safety is great enough, may risk exposure to use of force to prevent the defeat of inner perimeter security.

C. Restricted Zone

1. The restricted zone includes the rest of MSP property.

2. Each of the roads in this area shall be controlled and restricted using road blocks, check points, or security patrols as described in TM 01/13, Crowd Control/Perimeter Security.

D. Extended Zone

1. The extended zone includes all non-MSP property adjacent to the prison boundaries.

2. Local law enforcement shall enforce traffic and parking laws and will be available to provide security as needed. 
A. The authority to protect and enforce the laws and regulations relating to these security zones are assigned to peace officers who have powers of arrest. Officers who wish to be advised concerning the appropriateness of arrests in particular situations may request assistance from the Warden or designee and/or Special Response Team Commander in such cases.

B. The Powell County Sheriff's Department shall provide arrest teams for use, if needed, to transport violators to jail.

C. Other backup units, including the Montana Highway Patrol, may be available to assist in controlling the security zones.

TM 01/11.04 Duration of Security Zones

A. For purposes of the execution, the security zones shall be fully operational a minimum of seven hours prior to the execution and a minimum of two hours following the execution.

B. Security zone regulations shall revert thereafter to the requirements of the Montana State Prison Policy and Procedures Manual.

TM 01/11.05 Escort Through Security Zone

During the execution, it may be necessary to provide access/escort to local residents. All cases will be cleared by the Operations Section Chief (Security Major). 
TM $01 / 12.01$

TM $01 / 12.02$

TM $01 / 12.03$

TM $01 / 12.04$

TM $01 / 12.05$

TM $01 / 12.06$

TM $01 / 12.07$

TM $01 / 12.08$

TM $01 / 12.09$
General Provisions

Order of Arrival at the Execution Site

Witnesses Transported from the Staging Areas

Escort/Transportation Teams

Transportation to Execution Chamber

Returning Witnesses to Wallace Building

Executioners

State Medical Examiner/Coroner

Transportation Procedures for the Condemned 
TM 01/12.00 ESCORT/TRANSPORTATION

TM 01/12.01 General Provisions

A. Purpose of Chapter

The purpose of this chapter is to:

1. provide the transportation/escort policies and procedures during the execution event for:

a. news media witnesses;

b. the condemned inmate's invited witnesses;

c. state witnesses to the execution;

d. the Executioners;

e. the State Medical Examiner/Powell County Coroner; and f. and the condemned.

2. identify the duties of the Escort/Transportation Officers.

B. $\quad \underline{\text { Policy }}$

It is the policy of the Department that:

1. movement to the Execution Chamber shall be strictly controlled;

2. witnesses to the execution shall be escorted to and from the Execution Chamber;

3. the Executioners shall be transported to and from the execution operations room in a manner which ensures their timely arrival and maintains the confidentiality of their identities;

4. Officers assigned to escort witnesses shall remain with them to and from assigned locations;

5. those assigned to escort/transport the Executioner(s) shall locate and identify them through a confidential prearranged process; 
6. the County Coroner shall be provided escort between the Wallace Building, the Execution Chamber and the state Crime Lab;

7. the Setup Officer will be transported by an Administrative staff member from the Wallace Building to the execution chamber;

8. those assigned to escort/transportation duties and their backups shall assume other security duties as defined in this chapter; and

9. sufficient redundancy shall be built into the system to ensure that escort/transportation schedules can be met even if one or more members of an escort/transportation team is disabled.

TM 01/12.02 Order of Arrival at the Execution Chamber

For those to be escorted/transported to the Execution Chamber, the order and times of arrival shall be:

A. The setup officer will arrive a minimum of one hour prior to the scheduled execution.

B. The execution team will arrive approximately one hour prior to the scheduled execution.

C. State witnesses will arrive five minutes prior to the scheduled execution.

D. The condemned inmate's witnesses will arrive four minutes prior to the scheduled execution.

E. The victim witnesses will arrive three minutes prior to the scheduled execution.

F. News media witnesses will arrive two minutes prior to the scheduled execution.

TM 01/12.03 Witnesses Transported from the Staging Areas

A. Assembly/Holding Rooms

1. The victim and state witnesses shall be kept at the Ranch I Business Office. 
2. The news media witnesses shall be kept at the media staging area at the Training Center.

3. The condemned inmate's witnesses shall be staged in the escort vehicle.

B. $\quad$ Preliminary Call/Processing

1. When ordered by a Warden or designee, the Escort

Team shall notify those they are to escort between the staging area and the Execution Chamber that they are ready to begin the countdown to process them for escort.

The state and victim witnesses shall be:

a. Staged at a designated location in the Wallace Building for briefing.

b. The selected news media witnesses shall be briefed and searched at the media staging area.

c. The condemned inmate witnesses shall be briefed and searched at the pickup point.

d. As needed, the Ranch I Office may be used for additional staging.

2. Each witness shall be required to empty his pockets. The witnesses will be asked to return any disallowed items to their vehicle. To avoid unnecessary delays in processing, witnesses should leave all personal property in their vehicles. No purses, briefcases, books, valuables or other materials may be retained, except that:

a. the designated clergy may retain one Bible or other religious book (subject to search) and approved religious items;

b. the press shall be permitted to retain a small 6" $\mathrm{x}$ 9" notebook and two pens or pencils; and

c. any witness requiring prescription eye glasses may retain them.

3. All witnesses shall then be required to submit to a clothed body search and passing of metal detector consistent with TM $01 / 16$. 
a. Immediately following the search of a witness, the witness shall be required to remain in the area until permitted to exit.

b. Anyone refusing to be searched or surrender property shall be denied access to the execution site.

TM 01/12.04 Escort/Transportation Teams

A. The makeup of escort/transportation teams shall include:

1. one officer for the state witnesses;

2. one officer for the condemned inmate's invited witnesses; and

3. one officer and/or the Public Information officer for the news media.

TM 01/12.05 Transportation to Execution Chamber

Departure shall be in the order of intended arrival at the Execution Chamber, and shall be timed for arrival three to five minutes prior to the scheduled execution time.

1. The state witnesses shall depart first.

2. The condemned inmate's invited witnesses shall depart second.

3. The victim witnesses shall leave third.

4. The news media witnesses shall depart last.

TM 01/12.06 Returning Witnesses to Wallace Building

After the execution, all witnesses shall be returned to the Personnel Building, with the exception of the news media, who will be escorted to the media staging area. All witnesses shall be required to surrender their security passes and escorted off state property.

TM $01 / 12.07 \quad$ Executioners

A. The Warden or designee shall arrange for the Executioners to go to a specific location or locations. The only persons who shall know the meeting location shall be: 
1. the Warden or designee;

2. the Executioners.

B. The Executioners shall be brought to the Execution Chamber approximately one hour prior to the execution. They shall then be escorted into the execution operations room where they shall remain throughout the execution.

C. Following the execution, the Executioners shall be transported back to the pickup location by the Warden or designee.

D. Vehicles transporting Executioners shall not be searched. Escort drivers shall have identification cards coded for "no-search access" to the site.

E. The windows of the Executioners' transport vehicle shall be covered to prevent anyone from looking in.

TM 01/12.08 State Medical Examiner/Coroner

A. To the Execution Site

Law enforcement officers shall provide escort to the coroner to the execution site.

B. From the Execution Site

The Montana Highway Patrol shall escort the Coroner or designee from Montana State Prison to the State Crime Lab in Missoula.

TM 01/12.09 Transportation Procedures for the Condemned after Issuance of Death Warrant

A. Onsite Escort and Transportation

Every effort will be taken to avoid escort of the condemned out of the Maximum Security building, once the death warrant has been issued.

If it is necessary to escort the condemned out of Maximum Security, a minimum of two correctional officers will be required for escort.

B. Offsite Transportation

The condemned will not be transported outside the double fence perimeter unless in full hard restraints. The only exception to this is when life saving medical attention is necessary offsite. 
TM 01/13.00 CROWD CONTROL/PERIMETER SECURITY

TM 01/13.01 General Provisions

TM 01/13.02 Check Point Locations/Responsibilities

TM 01/13.03 Passes/ID/Authorization

TM 01/13.04 Control Measures 
TM 01/13.00 CROWD CONTROL/PERIMETER SECURITY

TM 01/13.01 General Provisions

A. Purpose of Chapter

The purpose of this chapter is to:

1. provide the purpose and operational procedures for crowd control and control of the prison's restricted zones;

2. identify the various check points and security units assigned to control access to the prison; and

3. identify and define the control measures which will be used to ensure the security of the institution during the execution.

B. Policy

It is the policy of Montana State Prison that:

1. persons arriving at or driving past Montana State Prison shall be routed and controlled in a manner which:

a. does not compromise or inhibit:

(1) security;

(2) official escort or movement;

(3) the functions necessary to carry out the execution or

(4) safety; and

b. ensures efficiency of movement;

2. persons controlled/handled through this procedure shall:

a. be handled in a manner which involves no more restriction than is necessary to carry out the legitimate interests of the prison; and

b. be dealt with in a courteous manner;

3. procedures for crowd control shall be consistent with federal, state and local laws. 
4. only persons specifically authorized by security pass or prison identification will be permitted on prison property; and

5. persons entering Montana state Prison property without authorization shall be ordered to leave and may be arrested if:

a. the trespass was intentional;

b. the trespass in any way jeopardizes the security of the institution.

TM 01/13.02 Check Point Locations/Responsibilities

There shall be three check point positions at the locations listed below:

A. $\quad$ Check Point \#1

This check point:

1. Shall be located at the intersection of the main road to the prison and the access road to the Golf Course/Doc Training Center (Old National Guard Armory).

2. Shall be responsible for clearance of all authorized witnesses, members of the press, and others approved to be at the prison during the execution.

3. Shall have a barricade erected to keep the roadway clear of onlookers/demonstrators.

4. Shall be responsible for security at the designated public assembly location, located in the field at the bottom of Golf Course Hill.

5. Shall be staffed by prison employees and law enforcement officers, including the Powell County Sheriff's Department and the Montana Highway Patrol. The sheriff's department will provide arrest powers with the highway patrol available to transport violators to the county jail.

B. Check Point \#2

1. Shall be located at the Check point building and will be responsible for routing media to the Training Center, and will be staffed by two prison employees. 
C. Security Patrol Units (Roaming Check Point \#3)

1. One two-man prison vehicle will continually patrol the area between Check Points 1, 2 and the south entrance and shall provide back-up as well as relief to the checkpoints.

2. One two-man prison vehicle will patrol the area including old Stage Road, Airport Road, and Golf Course Road.

3. Security Patrols may be required to provide escort to incoming vehicles.

4. At 1600 hours, on date of execution a security patrol unit will secure the Ranch 2 gate.

TM 01/13.03 Passes/ID/Authorization

Refer to TM 01/14 and TM 01/15.

TM 01/13.04 Control Measures

A. Passive control measures shall be employed whenever possible as a non-aggressive means to inform, control and manage individuals and civilian groups. Passive control measures may include:

1. posting of signs in conspicuous locations giving directions, regulations and/or other pertinent information; and

2. placing of barriers at strategic locations to control or restrict access.

3. May include up to three verbal directions.

4. Written handouts with regulations or information.

B. Local law enforcement and the Montana Highway Patrol may accompany prison staff or may be called on site at the Check Point \#1 location to:

1. gather intelligence concerning any illegal activity directed by the crowd against the prison, demonstrators or other spectators;

2. diffuse conflicts between individuals;

3. present a calming influence throughout the crowd; 
4. isolate and facilitate removal of instigators; and

5. be available for crisis management.

C. After a predetermined time, only persons specifically authorized on the Master Security Pass List shall be permitted on Montana State Prison property.

D. Anyone entering the restricted zone (all Montana state Prison property) without authorization will be subject to arrest for trespass by local law enforcement. 
TM 01/14.00 EXECUTION SECURITY PASS

TM 01/14.01 General Provisions

TM 01/14.02 Persons to Whom Passes Shall be Issued

TM 01/14.03 Pass Codes

TM 01/14.04 Issue and Return of Execution Security Passes 
TM $01 / 14.00$

EXECUTION SECURITY PASSES

TM 01/14.01 General Provisions

A. $\quad$ Purpose of Chapter

The purpose of this chapter is to:

1. set forth the policies and procedures concerning security access passes for executions at Montana State Prison;

2. provide colored security passes for the instant recognition of pre-approved witnesses, members of the news media and members of allied agencies; and

3. explain pass-issue procedures.

B. $\quad \underline{\text { Policy }}$

It is the policy of Montana state Prison that:

1. during the pre-execution and execution period, access to the Montana State Prison complex and surrounding areas shall be tightly controlled and regulated using an access pass system;

2. passes shall be issued to:

a. persons involved with the execution event;

b. witnesses to the execution; and

c. those members of the press either witnessing the execution or admitted to the staging area.

3. only those persons on the Master Security Pass List will be issued passes and/or admitted on prison property after 1700 hours on date of execution. Prison staff not on the list will not be allowed on-site without clearance from the Operations Security Chief.

TM 01/14.02 Persons to Whom Passes Shall be Issued

A. Passes shall be required for:

1. non-staff members on site and involved with the execution operation;

2. news media members witnessing the execution or authorized to 
be in the news media staging area; and

3. other statutorily authorized witnesses to the execution.

B. Passes shall be worn clipped to the outermost garment and visibly displayed.

TM 01/14.03 Pass Codes

Security passes shall be color-coded to clearly identify which category of persons the individual represents. The color code is as follows:

1. witnesses: red numbered identification with a large $W$ on it.

2. news media witnesses: blue background with a numbered identification with a large $\mathrm{M}$ on it.

3. general media at the staging area: blue background with a numbered orange strip.

TM 01/14.04 Issue and Return of Execution Security Passes

A. Persons shall be required to show picture ID at the time passes are issued for entry to Montana State Prison. Forms of identification that shall be accepted include:

1. a valid driver's license;

2. a Montana Driver's License Division identification card or;

3. a valid passport.

B. Only persons listed on the Master Security Pass List shall be processed for a security pass.

C. All security passes must be turned over to prison personnel prior to leaving Montana state Prison property. 
TM 01/15.00 MASTER SECURITY PASS LIST

TM 01/15.01 General Provisions

TM 01/15.02 Master Security Pass List

TM 01/15.03 Locations for Distribution

TM 01/15.04 On-Going Updates

TM 01/15.05 Omissions From and Challenges to Pass List 
TM 01/15.00 MASTER SECURITY PASS LIST

TM 01/15.01 General Provisions

A. Purpose of Chapter

The purpose of this chapter is to:

1. explain the purpose and function of the Master Security Pass List;

2. to provide the time frame for completion;

3. to establish the distribution list and the time for distribution for each;

4. to determine the locations/posts requiring a Master Security Pass List; and

5. to discuss the on-going update process.

B. Policy

It is the policy of the Montana state Prison that:

1. Master Security Pass Lists shall be distributed as provided in TM $01 / 15.03$.

2. for each person approved for a security pass, the Master Security Pass List shall include:
a. name;
b. designation; and
c. color code, if appropriate.

3. all persons, including staff members, to be admitted after 1700 hours the day preceding the execution to the controlled and restricted areas must appear on the Master Security Pass List; and

4. persons not on the Master Security Pass List shall require special clearance from the Operations security Chief for admittance. 
TM 01/15.02 Master Security Pass List

The Master Security Pass List shall serve as a double-check in the event passes are counterfeited or stolen. Before entry is permitted an individual must have a security pass, and be approved for the zone or area he seeks to enter.

A. The Master Security Pass List shall be completed no later than 72 hours prior to an execution.

B. The Master Security Pass List shall be distributed to the authorized security posts as each becomes operational.

TM 01/15.03 Locations for Distribution

A. The following posts or locations shall be issued a Master Security Pass List:

1. Warden or designee's office;

2. Operations Security Chief;

3. each check point position;

4. the Wallace Building Lobby Entrance/Command Post;

5. Mobile Patrols; and

6. Incident Commander.

B. Any additional distribution shall be only with the approval of the Operations Security Chief.

TM 01/15.04 On-Going Updates

A. Extenuating circumstances, schedule changes and other factors may require last-minute changes on the master list.

B. When changes are required they shall be submitted to the Operations Security Chief by authorized administrators/supervisors for addition to lists and notification of all posts listed under TM $01 / 15.04, \mathrm{~A}$.

C. Persons who may approve changes and/or notify the Operations Security Chief of changes include:

1. the Warden; 


\section{Associate Warden(s)}

D. Updates shall be provided by radio or telephone to the appropriate locations/posts by the Warden or designee and Operations Security chief.

TM 01/15.05 Omissions From and Challenges to Pass List

A. Persons, including staff members, admitted to controlled and restricted areas after 1700 hours the day preceding the execution must be listed on the Master Security Pass List.

B. If persons are omitted inadvertently or claim to be improperly omitted, the matter shall be directed to the operations security chief or Command Post for instructions.

1. The Operations Security Chief shall independently verify or disallow the individual's claims of authorization for entry to the location to which he seeks access. 
TM 01/16.00 SEARCHES

TM 01/16.01 General Procedures

TM 01/16.02 Execution Search

TM 01/16.03 Holding Cell

TM 01/16.04 Search of Condemned Inmate at Time of Move to Death Watch

TM 01/16.05 Personal Searches of Witnesses

TM 01/16.06 Executioner Searches 
TM 01/16.00 SEARCHES

TM 01/16.01 General Provisions

A. Purpose of Chapter

1. The purpose of this chapter is to provide the policy and procedures for search requirements in conjunction with the execution.

2. Searches covered shall include property and building searches including:

a. general searches of Montana State Prison;

b. the Wallace Building;

c. the execution area; and

d. the death-watch area/holding cell.

3. Procedures shall also cover vehicle and clothed body searches.

B. Policy

1. Montana State Prison shall search facilities and property as a precaution against safety or security problems. Such searches shall be as thorough as the intent of the search requires.

2. Witnesses to the execution shall be pat-searched by a person of the same sex.

3. No strip search of any witness shall be conducted. If the witness is suspected of concealing weapons, drugs or any other item not expressly authorized, he will not be permitted to attend and will be turned over to local authorities.

TM 01/16.02 Execution Building Search

A search of the Execution Chamber shall be conducted on the day preceding the execution, after 1200 hours.

TM 01/16.03 Pre-Execution Holding Cell

A. The holding cell shall be carefully swept and cleaned prior to the 
search.

B. The holding cell shall be searched at least one hour prior to the condemned inmate's move to that cell.

C. Immediately prior to putting the inmate into the holding cell, the Death-Watch Officer shall search the cell again.

TM 01/16.04 Search of Condemned Inmate at Time of Move to Holding $\underline{\text { Cell }}$

A. Moving the Condemned to the Holding Cell

1. When administrative activities become disruptive to the routine of the cell block, or the condemned/inmates on the block become disruptive, the condemned shall be moved to the holding cell. In no case should this be done later than 0800 on the day prior to the scheduled execution.

2. Without warning and as directed by the Warden or designee, a three man team shall enter the condemned inmate's cell, restrain him in handcuffs and leg irons and escort him to the shower area.

3. The condemned shall be allowed to leave his cell with nothing but the clothing and restraints he is wearing.

4. The condemned inmate shall then be carefully strip searched and issued a short-sleeve jump suit and shower thongs to wear to the holding cell.

5. The condemned shall then be escorted to the holding cell by the death-watch team.

B. Securing Condemned Inmate's Property/Cell

1. Whenever possible, the inmate will make arrangements to pack and inventory his property with the Property officer prior to his move to the holding cell.

2. After transferring the condemned inmate to the holding cell, the two person Maximum Security search team which searched the holding cell shall enter the cell from which the condemned was removed.

3. One member of the team shall search while the other member inventories and documents the search. 
a. The searching member shall call out each item to be inventoried for the recording member to log. 
b. Each item secured shall be searched carefully for:

(1) contraband;

(2) indications of an escape plan;

(3) indications of suicide plans; and

(4) other information which would indicate possible problems during the final hours leading to execution.

c. All personal mail shall be read for:

(1) indications of escape/rescue plans;

(2) indications of suicide plans;

(3) indications of outside interference with the execution; and

(4) other information which would indicate possible problems during the final hours leading to execution.

4. Personal property shall be separated from prison property, and the personal property put into a suitable container and sealed. Each search team member shall initial the seal.

5. The search team shall then reverse roles and the second member shall search the "clean" cell to attempt to discover anything missed in the first search.

6. The cell shall then be locked until ready for reassignment. Reassignment shall not occur for 48 hours after the execution, in case an additional search of the cell is required.

7. Any personal property shall be taken to the property room for storage.

TM 01/16.05 Personal Search of Witnesses

A. General

1. News media representatives and inmate-invited witnesses shall be searched at the Wallace Building prior to being escorted to the staging area or the Execution Chamber. 
2. Each witness shall be required to empty his pockets. The witnesses will be asked to return any disallowed items to their vehicle. To avoid unnecessary delays in processing, witnesses should leave all personal property in their vehicles. No purses, briefcases, books, valuables or other materials may be retained except that:

a. the designated clergy may retain one Bible or other religious book (subject to search) and approved religious items;

b. the press shall be permitted to retain a small 6" $\mathrm{x} 9$ " notebook and two pens or pencils; and

c. any witness requiring prescription eye glasses may retain them.

3. Allied agency officials, the coroner and the state Medical Examiner shall be searched by metal detector, but shall not be pat-searched unless there is suspicion that an official is carrying contraband.

4. Strip search of witnesses shall not be permitted.

TM 01/16.06 Executioner Searches

Executioners and the vehicle transporting them shall not be searched. 
TM 01/17.00 CONTINGENCY PLANS

TM 01/17.01 General Provisions

TM 01/17.02 General Contingencies

TM 01/17.03 Specific Contingencies

TM 01/17.04 Additional Procedures 
TM 01/17.00 CONTINGENCY PLANS

TM 01/17.01 General Provisions

A. $\quad$ Purpose of Chapter

1. The purpose of this chapter is to provide an outline of plans developed to handle contingencies that may occur during an execution.

2. Full detail will not be provided for each procedure or event in this chapter. For detail, reference will be made to chapters where such detail may be found.

B. $\quad \underline{\text { Policy }}$

It is the policy of the Montana state Prison that;

1. contingencies be planned for and sufficient manpower and equipment be available to carry out such contingency plans;

2. redundancy of manpower be sufficient for critical functions to ensure the capability of proper response; and

3. contingency teams and manpower shall be staged at strategic locations which shall ensure immediate availability and response to exigent situations.

TM 01/17.02 General Contingencies

A. Availability

A team of officers shall be staged on-site and shall be available to assist in contingencies that require additional officers or replacement of an officer.

B. Available Units

1. Tactical and arrest teams from Montana State Prison and allied law enforcement agencies;

2. ambulance;

3. fire suppression units; and

4. others, as needed. 
A. $\quad$ Critical Incidents

1. A tactical team shall be staged on prison property to assist in resolving critical incidents, including life-threatening or hostage situations.

2. Unless the particular incident directly involves the condemned, it shall be handled by isolating the event and allowing the execution to proceed without interruption.

3. The Warden or designee will be informed of all incidents of a critical nature and will make the determination regarding whether to halt the execution proceedings.

B. Hostage Situation

1. A hostage situation involving the condemned inmate shall require resolution prior to continuing with the execution countdown.

2. A hostage situation not involving the condemned inmate shall be handled by isolating the event and simultaneously handling it and the execution as independent actions.

3. If the hostage situation does not directly involve the condemned as a participant, but is intended to free the condemned or halt his execution:

a. no release from custody of the condemned shall be permitted;

b. the prison's tactical teams and negotiation team shall be employed to execute the prison's tactical procedures for hostage situations if the hostage situation is on Montana State Prison properties;

c. if the hostage situation is off Montana State Prison property, the agency of appropriate jurisdiction shall be asked to respond; and

d. decisions concerning when and how to proceed with the execution shall be referred to the Warden or designee.

\section{Maintenance}

A team of maintenance employees shall be staged near the execution 
site to be readily available to handle maintenance contingency functions.

D. $\quad$ Fire

The Command Post shall be responsible for directing and escorting fire units to the appropriate location, and for maintaining security in the fire area.

TM 01/17.04 Additional Procedures

\section{A. Check Points/Security Posts}

1. Check points and additional security posts have been created to control traffic, provide security and handle contingencies that may develop.

2. Refer to TM 01/11 and TM 01/13. 
TM 01/18.00 TRAINING AND BRIEFING

TM 01/18.01 General Provisions

TM 01/18.02 Training and Briefing Components 
TM 01/18.01 General Provisions

A. $\quad$ Purpose of Chapter

The purpose of this chapter is to provide the policy and procedure concerning briefing and training of staff, members of allied agencies and others involved in an execution.

B. $\quad \underline{\text { Policy }}$

It is the policy of Montana state Prison that staff and others involved in carrying out an execution:

1. receive comprehensive briefings covering:

a. their duties and responsibilities;

b. the specifics of post orders covering assigned positions;

c. communication and chain of command; and

d. overview of functions and activities during the execution.

2. receive the level of briefing and training necessary based on the requirements of assigned duties;

3. rehearse and practice functions which involve:

a. difficult timing;

b. a high degree of skill;

c. procedures of a highly critical nature; and/or

d. moderately difficult or complex interaction with others.

4. receive instructions concerning backup systems to provide:

a. problem-resolution assistance;

b. policy decisions; 
c. crisis management assistance; and

d. information requests.

TM 01/18.02 Training and Briefing Components

A. General

Training and briefing shall include, but not be limited to:

1. issuing a post order for the assigned positions, as needed;

2. providing an orientation or briefing covering assigned duties and general operational information;

3. if necessary, detailed training covering legal, operational or technical aspects of assigned position;

4. if necessary, rehearsal of job functions; and

5. for key positions, Manual TM 01 .

B. $\quad$ Post Orders

1. Each member or other participant shall be issued the post orders for his assigned position, if deemed necessary.

2. When appropriate, one or more chapters of TM 01 may be issued with a post order.

3. All post orders (and any accompanying manual material) shall be returned at the completion of the execution event.

C. Briefing/Orientation

1. Most assignments will be very specialized, involving a narrow range of duties. For such positions, briefing/orientation sessions will be all the training required in addition to the general training skills and experience of the person assigned.

2. Orientation sessions shall include, but not be limited to:

a. an overview of the execution process and operational components;

b. location of assigned posts;

c. chain of command and organizational information; 
d. an overview of the countdown of activities and procedures leading to the execution;

e. an explanation of support and crisis intervention systems;

f. interaction with news media;

g. a review of the specific post order requirements, duties and other elements; and

h. a question-and-answer period.

D. Training/Rehearsal

1. For assignments requiring more technical or complex functions, critical timing or interaction elements, or duties of a particularly difficult nature, more comprehensive training shall be required.

2. Training and rehearsals will be scheduled for the following positions:

a. Executioner/alternate;

b. Setup Officer;

c. Tie-Down Officer;

d. Death Watch Officer;

e. Escort Officers;

f. Check Point/Perimeter Security Officers;

g. those assigned to the execution/information center.

3. Joint practices and rehearsals will be scheduled as needed. 
TM 01/000 POST ORDERS:

TM $01 / \mathrm{PO} 1$

TM $01 / \mathrm{PO} 2$

TM $01 / \mathrm{PO} 3$

TM $01 / \mathrm{PO} 4$

TM $01 / \mathrm{PO} 5$

TM $01 / \mathrm{PO} 6$
Death Watch Officer

Tie Down Officer

Escort Officer

Check Point Officer

Setup Officer

Executioner: Lethal Injection 
Post Order: Institutional Operations

TM 01/PO1 DEATH WATCH OFFICER (6)

Table of Contents

TM 01/PO1.00 DEATH WATCH OFFICER

TM 01/PO1.01 General

TM 01/PO1.02 Duties and Responsibilities 
TM 01/PO1.00 DEATH WATCH OFFICER

TM 01/PO1.01 General

A. $\quad$ Purpose of Chapter

The purpose of this chapter is to:

1. provide the working title, location of assignment and supervisory/ subordinate level;

2. list the duties and responsibilities for the position.

B. $\quad$ Policy

It shall be policy of Montana State Prison:

1. to provide, during the last 24 hours or more prior to the execution, a death-watch procedure which will involve housing of the inmate in a special cell or cells with:

a. constant observation provided by a death-watch staff;

b. control and observation of all communication between the condemned inmate and others;

c. control of all items to which the condemned shall have access; and

d. special precautions against suicide or other self destructive behavior which might prevent or delay the execution; and

2. to maintain a log of significant activities of the condemned inmate.

C. Definitions

Pre-Execution/holding cell The final holding area where the condemned inmate is housed prior to the execution being carried out.

TM $01 /$ PO1.02 Duties and Responsibilities

A. General Duties and Responsibilities

The Death Watch Officer position: 
1. Shall be filled by Montana State Prison correctional officers; and

2. under general supervision of the Security Major or designee will be responsible for monitoring, supervising and logging significant activities of the condemned inmate during his confinement in the death-watch holding cell.

B. $\quad$ Specific Duties and Responsibilities

1. Pre-Execution

The Death Watch Officer position:

a. the Security Major and Max Unit Manager shall review all volunteer applications for Death Watch Officers and will mutually agree on assignments.

b. shall be a three-person team with two specifically assigned officers, and one officer from the regular Maximum Security staff on-shift the day of the execution. One officer will be stationed outside the inmate's cell with a direct view of the inmate. A second officer will be stationed on the block, by the block door, with a direct view of the first officer. The third officer will be a backup, with the three officers alternating positions each hour;

c. one Death Watch Officer shall conduct a search of the holding cell prior to placing condemned into the cell;

d. at least one officer shall remain at the holding cell to maintain security immediately following the search until such time as the condemned inmate is placed in the cell;

e. shall not leave his assigned post until properly relieved;

f. shall keep the entrance to the holding cell area secured at all times, except to allow entrance of individuals authorized by the Warden or designee;

g. Shall not enter the cell unless exigent circumstances require entry, and only after summoning the assistance of other officers. (Exigent circumstances would include suicide attempts or serious medical problems.)

h. shall constantly observe the condemned inmate; 
i. shall document on a log set up specifically for the death watch period, significant activities which include but are not limited to:

1) eating;

2) reading;

3) Visits;

4) comments;

5) Sleeping;

6) showers;

7) outbursts of anger, rage, etc; and

8) suicide attempts or gestures.

j. shall limit items given to the condemned inmate to the approved list below and to require their return immediately after use if not consumed:

1) a toothbrush (1);

2) toothpaste (shall be applied to toothbrush by Death Watch Officer); and

3) a battery-operated electric shaver.

4) medication, as issued by the Infirmary on doctor's orders.

k. if the condemned inmate receives mail:

1) provide the letter to the condemned inmate; and

2) ensure that no more than one letter at a time is permitted in the cell; and

1. if the condemned inmate requests, allow on an exchange basis in the holding cell;

1) a Bible or other religious book;

2) a magazine (one at a time); 
3) a newspaper;

4) photographs;

m. shall ensure that the following procedures are followed for visits:

1) immediate family and/or approved visitors will be allowed non contact visits in numbers to be established by the Security Major prior to the inmate moving to the holding cell;

2) once moved to the holding cell, only attorney and clergy will be allowed to visit until a pre-designated time;

3) the chaplain, approved by the Warden or designee, may visit throughout the death watch, but his visits shall not interrupt other necessary functions, nor be conducted in a manner that would jeopardize security and order.

4) telephone privileges shall be suspended at 1500 hours on date of execution, unless authorized by the Warden or designee.

5) no personal visits, except clergy and attorney will be allowed after 1030 hours the day of the execution.

6) attorney visits shall be terminated in sufficient time to permit the preparation process during the final countdown.

7) visits will be suspended if they jeopardize the safety, security, management and control of the holding cell area or Maximum Security Building or if the inmate becomes unmanageable.

\section{Execution}

The Death Watch Officer position (2200 - 0200 hrs shift)

a. shall remain at the holding cell to maintain security until properly relieved by order of the Warden or designee or designee;

b. in the event of a stay or delay of execution, shall 
resume the responsibility of supervising the condemned inmate's activities following his return to the holding cell;

c. shall ensure that the death-watch log is turned over to the Associate Warden of Security;

d. shall report to the Warden or designee's Conference Room for debriefing.

Post Order: Institutional Operations

TM 01/PO2 TIE-DOWN OFFICER (4)

Table of Contents

TM 01/P02.00 TIE-DOWN OFFICER

TM 01/PO2.01 General

TM 01/PO2.02 Duties and Responsibilities 
TM $01 /$ PO2.01 General

A. $\quad$ Purpose of Chapter

The purpose of this chapter is to:

1. provide the working title, location of assignment, and supervisory/ subordinate level;

2. list the duties and responsibilities for the position.

B. $\quad$ Policy

It shall be the policy of Montana state Prison:

1. to provide supervision and security of the condemned inmate when he is escorted to the Execution Chamber;

2. to ensure that the condemned inmate is secure in the execution apparatus;

3. following the execution, that the Tie-Down Officers assist as needed in removing the executed inmate from the execution apparatus; and

4. that the Tie-Down Officers assist the State Medical Examiner/designee, as appropriate, in removal of the executed inmate from the Execution Chamber.

5. that cleanup be completed at the Execution Chamber by the Tie-Down Team.

TM $01 /$ PO2.02 Duties and Responsibilities

A. General Duties and Responsibilities

The Tie-Down Officer:

1. shall be a correctional staff member;

2. is responsible to escort the condemned inmate from the holding cell to the Execution Chamber and to strap the condemned inmate on to the gurney.

B. $\quad$ Specific Duties and Responsibilities/Lethal Injection

1. $\quad$ Planning 
The Tie-Down Team shall be comprised of four members and two alternates.

\section{Pre-Execution}

The Tie-Down Officer:

a. shall strip search the condemned, then dress out in a clean, orange, short sleeve jumpsuit;

b. shall restrain the condemned with handcuff and leg irons;

c. shall escort the inmate from the holding cell to the execution site;

d. shall be positioned as follows when transferring the condemned inmate from the holding cell to the Execution Chamber:

1) one officer directly in front of the condemned inmate;

2) two officers positioned on each side of the condemned inmate holding on to the condemned inmate's arm; and

3) one officer directly behind the condemned inmate.

4) If the condemned becomes faint or weak, and is unable to walk to the execution chamber, or if the condemned becomes disruptive and will not comply with the transfer to the execution chamber, the following procedure will be utilized.

a) Apply full restraint to the condemned using handcuffs, leg irons, and belly chains.

b) Secure the condemned to the spine board in the following fashion:

1) Pre-position the polypropylene webbing on the spine board in the following areas; ankles, above the knees, waist, and chest.

2) Place the condemned on the spine board face up.

3) With the tie down officers positioned the same for tie down to the gurney, 
strap the condemned to the spine board in the following order; ankles, above the knees, waist, and then chest.

4) The condemned will then be carried to the execution chamber by the tie down team and secured to the gurney on the spine board.

e. shall perform their respective assigned function by affixing the tie-down straps to the body of the condemned inmate as outlined below:

1) there shall be one Tie-Down Officer positioned on each side at the bottom of the gurney by the condemned inmate's feet;

2) there shall be one Tie-Down Officer positioned on each side by the condemned inmate's arms;

3) the condemned inmate shall be ordered to sit on the gurney. The Tie-Down Officers shall assist by lifting his feet in position on the gurney and assisting the condemned inmate to lie down;

4) the condemned inmate shall be strapped on the gurney as follows:

a) the condemned inmate's ankles and the strap across his chest shall be buckled down simultaneously by the Tie-Down Team;

b) One officer shall then release the restraints on the condemned inmate's hands, one at a time;

c) the officers positioned on each side by the condemned inmate's arms shall immediately secure the condemned inmate's wrist to the gurney;

d) the Tie-Down Team officers positioned at the condemned inmate's arms shall then place the straps across the abdomen, above the knees, and below the knees on the condemned inmate;

e) during the time the straps are being placed on the condemned inmate as outlined in "d" above the Tie-Down Officers positioned at the 
condemned inmate's feet shall remove the leg restraints and ensure the tie-down strap remains secure;

f. if the condemned inmate struggles or resists efforts to secure him, the condemned inmate shall be secured with the Tie-Down Team using force to secure the condemned inmate;

g. at the direction of the Warden or designee, the Tie-Down Team shall exit the Execution Chamber, and shall not be in a position to witness the execution;

h. upon completion of the execution, and as directed by the Warden or designee, the Tie-Down Team shall enter the Execution Chamber and remove the straps in the reverse order as outlined above;

i. in the event of a stay or delay of execution, the following procedures shall be followed:

1) at the direction of the Warden or designee, the officers shall re-enter the Execution Chamber;

2) place leg irons on condemned inmate;

3) release security straps on wrists and place handcuffs on the condemned inmate;

4) release the remaining security straps from the condemned inmate;

5) transfer to holding cell; or, if necessary,

6) release to medical personnel for life sustaining procedures and/or transportation to the nearest medical facility; as determined by the attending physician and as directed by the Warden or designee; and

j. shall direct any questions to the Warden or designee.

3. Execution

The Tie-Down Team shall remain immediately outside the Execution Chamber but not in a position to view the execution;

4. Post-Execution

The Tie-Down Team:

a. at the direction of the Warden or designee, the Tie-Down 
Team shall re-enter the Execution Chamber;

b. shall remove the security straps in the reverse order which they were placed on the body;

c. shall remove the body from the gurney and prepare to move the body to the awaiting transport vehicle; and

d. shall assist placing the body in the transport vehicle under the direction of the state Medical Examiner.

5. $\quad$ Cleanup

The Tie-Down Team shall be responsible for cleanup of the Execution Chamber after the chamber is cleared.

6. Debriefing

The Tie-Down Team shall assemble in the Warden or designee's Conference Room for debriefing. 
Post Orders: Institutional Operations

TM $01 / \mathrm{PO}$ ESCORT OFFICER (2-3)

Table of Contents

TM 01/PO3.00 ESCORT OFFICER

TM 01/PO3.01 General

TM 01/P03.02 Duties and Responsibilities 
TM $01 /$ PO3.00 ESCORT OFFICER

TM $01 /$ P03.01 General

A. $\quad$ Purpose of Chapter

The purpose of this chapter is to:

1. provide the working title, location of assignment, and supervisory/ subordinate level;

2. list the duties and responsibilities for the position.

B. $\quad$ Policy

It shall be the policy of the prison:

1. to require that witnesses authorized to enter or exit the Montana State Prison to view the execution be escorted by a prison staff member; and

2. to maintain order and protect the privacy of witnesses attending the execution.

TM 01/P03.02 Duties and Responsibilities

A. $\quad$ Specific Duties and Responsibilities

1. $\quad$ Pre-Execution

The Escort Officer:

a. shall, if necessary, attend a training class prior to an execution on how to perform a pat search;

b. shall assist in providing security at civilian waiting locations;

c. shall direct inmate-invited witnesses and state witnesses to the Warden or designee's Conference Room;

d. shall confer with the Public Information Officer as needed on escort arrangements for the news media;

e. shall not allow purses, briefcases, books, valuables or other materials to be retained except:

1. the designated clergy may retain one Bible or religious book and approved religious items; and 
2. prescription eye glasses;

3. for designated media persons, a notebook (6"x 9") and 2 pens/pencils.

f. shall conduct a metal detector search and pat search of each family and media witness but shall not strip search;

9. shall conduct a metal detector search of state witnesses;

h. shall, if reasonable suspicion exists that a witness is carrying contraband, contact the Warden or designee to determine if the witness should be denied access to the prison;

i. shall, if the witness refuses to be searched, revoke his security pass and require the witness to leave;

j. shall proceed when ordered by the Warden or designee to the Execution Chamber;

k. shall notify the Warden or designee of the escort officer's arrival;

1. Shall require witnesses to remain outside until given permission to enter the Execution Chamber by the Warden or designee.

3. Execution

The Escort Officers are not required to remain with the witnesses during the execution, except at the direction of the Warden or designee.

4. $\quad$ Post Execution

The Escort Officer:

a. shall require the witnesses to remain in the viewing room until ordered to leave by the Warden or designee;

b. shall escort the witnesses to the Wallace Building;

c. shall return any stored personal property to the witnesses in exchange for the witnesses' security passes;

d. shall notify the Operations Security Chief that the witnesses are ready to be escorted off state property; 
e. shall, when the escort vehicle arrives, instruct the witnesses to exit the Wallace Building and leave the Montana State Prison site; and

f. shall complete any necessary or required reports.

5. Debriefing

The Escort Officer shall attend a debriefing in the Warden/designee's Conference Room following the execution. 
Post Orders: Institutional Operations

TM 01/P04 CHECK POINT OFFICER

Table of Contents

TM 01/PO4.00 CHECK POINT OFFICER

TM 01/PO4.01 General

TM 01/PO4.02 Duties and Responsibilities 
TM 01/PO4.00 CHECK POINT

TM $01 /$ PO4.01 General

A. $\quad$ Purpose of Chapter

The purpose of this chapter is to:

1. provide the working title, location of assignment, and supervisory/ subordinate level;

2. list the duties and responsibilities for the position.

B. $\quad$ Policy

It is the policy of Montana State Prison:

1. to establish and maintain check points at two strategic locations;

2. to restrict access through the check points to staff members and members of allied agencies having a security pass, and being listed on the Master Security Pass List;

3. to receive authorization from the Operations Security Chief to allow any person not possessing a security pass to enter the restricted area and to provide escort for same.

4. to provide escort for all traffic allowed on prison property after 1700 hours the day preceding the execution.

TM $01 /$ PO4.02 Duties and Responsibilities

A. General Duties and Responsibilities

The Check Point position:

1. is normally a dual agency post assignment with either the Powell County Sheriff's Office or the Montana Highway Patrol.

2. under general supervision controls traffic and restricts access into the area to authorized persons only; and

3. is supervised by the Operations Security Chief and shall direct official radio communication to him.

B. Specific Duties and Responsibilities

1. Pre-Execution 
The Check Point officer:

a. shall maintain the entrance to prison property using vehicles or barricades which are well marked;

b. shall stop all travelers;

c. shall allow traffic through the check point to authorized persons;

d. shall check the names of all those requesting admittance against the Master Security Pass List and shall require photo I.D. prior to allowing access;

e. shall work with law enforcement assigned to the post to ensure that all trespassers are escorted off property and/or arrested;

f. shall communicate with the Operations Security Chief on an on-going basis regarding any problems at the check point.

3. Execution

Continue normal duties.

4. $\quad$ Post Execution

a. The Check Point Officer shall continue with duties outlined in pre-execution until ordered otherwise.

b. The officers at Check Point \#1 shall ensure all MSP execution security passes are returned.

5. Debriefing

a. The Check Point Officer shall prepare necessary written reports for the Operations security Chief to submit at the debriefing.

b. The Check Point Officer will attend a debriefing in the Warden or designee's Conference Room following the execution. 
Post Orders: Institutional Operations

TM 01/PO5 Setup Officer

Table of Contents

TM 01/P05.00 Setup Officer

TM 01/P05.01 General

TM 01/P05.02 Duties and Responsibilities 
TM 01/P05.01 General

A. $\quad$ Purpose of Chapter

The purpose of this chapter is to:

1. provide the working title, location of assignment, and supervisory/ subordinate level;

2. list the duties and responsibilities for the position.

B. $\quad$ Policy

It is the policy of Montana State Prison that the Setup Officer assist the Executioners in carrying out the sentence of death by lethal injection in a manner consistent with state law.

TM $01 /$ P05.02 Duties and Responsibilities

A. General Duties and Responsibilities

The Setup Officer:

1. shall be selected by the Warden or designee; and

2. under the direction of the Warden or designee as outlined in the state statutory regulations, shall assist in setting up the I.V. so that the Executioner may administer the lethal injection.

B. Specific Duties and Responsibilities

1. $\quad$ Pre-Execution

a. The setup Officer shall:

1) take receipt of the drug injection box and supplies from the Warden or designee and transfer it to the Execution Chamber;

2) complete a pre-inventory check of all equipment needed for the process.

2. Execution

a. The Setup Officer shall complete IV set-up as outlined below: 
1) the connector of Administration Set (Braun CDP 152 VSL) shall be inserted into the bag of Normal Saline IV solution;

2) the flow of solution shall be controlled by the Flo-Trol clamp located above the "Y" site;

3) a 35 inch Extension set Braun SCE 33 shall be connected to the needle adapter of the Administration set;

4) all connections should be taped to ensure they do not come apart during the procedure;

5) the tubing shall be cleared of air by removing the protector from the needle adapter and opening the Flo-Trol clamp letting the tube fill with solution;

6) then close the Flo-Trol clamp and replace the protective cap over the needle adapter; and

7) steps 1 through 6 shall be repeated for the second set-up.

\section{b. Setup Procedure}

The Setup Officer shall perform the following steps.

1) The angiocath shall be inserted into the vein of the left arm;

2) the inner needle is then withdrawn and the needle adapter is placed on the angiocath;

3) the flow of normal saline shall be started and administered at a slow rate (TKO - to keep open);

4) Step 1 through 3 shall be repeated for the right arm;

5) the administration sets shall be running at a slow rate of flow, and reading for the insertion of syringes containing the injection agents;

6) observation of both set-ups to insure they are both patent and functioning properly; and

7) no further action is necessary at this time. 


\section{Post-Execution}

a. The Setup officer or coroner, (at the coroner's direction) will draw serum samples as requested by the State Medical Examiner or other authorized authority in the following manner immediately following the execution but no later than one hour:

From non-used IV setup, $10 \mathrm{cc}$ of blood will be withdrawn to clear and shall be disposed of then. $30 \mathrm{cc}$ of blood will be withdrawn from same site and placed into two (2) grey top and one (1) red top tube. These tubes need to be labeled with condemned inmate's name, date and time, placed on ice and transported with the body to the state Crime Lab.

b. The equipment and lethal drugs will be passed through from the Executioner to the Setup officer.

c. Equipment and lethal drug syringes shall be placed in a box, sealed with tape, and turned over to the Medical Examiner for analysis, as part of the autopsy.

d. Any remaining equipment will be placed in a box and turned over to the designated DOC Investigations Bureau Personnel, to be secured.

e. The Setup Officer shall be responsible for the disposal of the medical equipment used for lethal injection. 
Post Orders: Institutional Operations

TM 01/PO6 EXECUTIONER: LETHAL INJECTION

Table of Contents

TM 01/PO6.00 EXECUTIONER: LETHAL INJECTION

TM 01/P06.01 General

TM 01/P06.02 Duties and Responsibilities 
TM $01 /$ P06.01 General

A. $\quad$ Purpose of Chapter

The purpose of this chapter is to:

1. provide the working title, location of assignment, and supervisory/ subordinate level;

2. list the duties and responsibilities for the position.

B. $\quad$ Policy

It is the policy of Montana state Prison to select Executioners to carry out the sentence of death by lethal injection in a manner consistent with state law.

TM 01/P06.02 Duties and Responsibilities

A. General Duties and Responsibilities

The Executioner:

1. shall be selected by the Warden or designee; and

2. under the direction of the Warden or designee, as outlined in the state statutory regulations and Department policy, shall administer the lethal injection.

B. $\quad$ Specific Duties and Responsibilities

1. Pre-Execution

a. Approximately one hour prior to the execution, the Executioner shall complete a pre-execution inventory and equipment check.

b. An inventory check list shall be completed, dated and initialed by the Executioner using the initials "EX". A copy of the checklist is included in this document. Items marked "A" in the code column shall be carried in to the Execution Chamber by the Executioner at the time of the execution.

c. Quantities of items in, or adjacent to, the cabinet in the Execution Chamber shall be at least those items marked "B" in the code column. 


\section{Lethal Injection Procedure}

1. When the signal to commence is given by the Warden or designee, the following procedures shall be followed with the Executioner administering a continuous intravenous injection simultaneously:

(a) the flow of the Normal Saline into the arm shall be cut off utilizing the Flo-Trol clamp;

(b) the clamp should be moved as close to the "Y" site as possible;

(c) the 18 ga needle of Syringe \#1 shall be inserted into the "Y" site and the injection shall commence;

(d) a slow, steady, even flow of the injection shall be maintained with only a minimum amount of force applied to the syringe plunger;

(e) when the entire contents of the syringe have been injected, Syringe \#l shall be removed from the "Y" site;

(f) the Flo-Trol clamp should then be opened fully and allowed to run for 15 seconds;

(g) the Flo-Trol clamps will then be closed;

(h) the Executioner will await for the appropriate signal from the Warden or designee to proceed on with the \#2 syringe or administer the backup \#1 syringe after the Warden or designee reviews level of consciousness;

(i) at the direction of the Warden or designee the \#2 syringe shall be inserted into the "Y" site;

(j) the entire contents shall be injected with slow even pressure;

(k) when the contents of the \#2 syringe have been injected, the Flo-Trol clamp should be fully opened and remain open until the attending qualified official examines the inmate and pronounces death;

(1) if at any time one of the lines become blocked and 
the flow ceases the lethal injection shall be injected into the line which is not blocked.

\title{
3. Post-Execution
}

a. The Executioner will transfer the equipment and lethal drugs through the pass-through to the Setup officer.

\author{
$\mathrm{GB} / \mathrm{gmb} / \mathrm{drc}$ \\ $7-2-98$ \\ $\mathrm{RS} / \mathrm{mb}$ \\ $10-21-10$ \\ $\mathrm{RS} / \mathrm{mb}$ \\ $02-22-11$ \\ $\mathrm{CA} / \mathrm{mb}$ \\ $07-21-11$ \\ $\mathrm{CA} / \mathrm{mb}$ \\ 0 8-04-11 \\ $\mathrm{TW} / \mathrm{CB} / \mathrm{mb}$ \\ 10-09-12 \\ $\mathrm{CB} / \mathrm{mb}$ \\ 01-14-13
}

